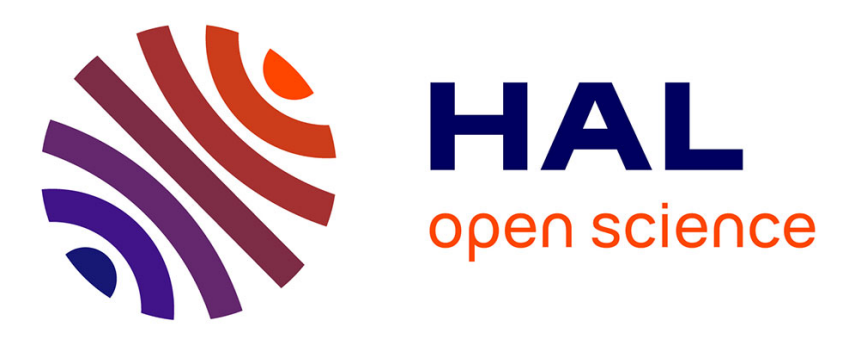

\title{
Pyrolysis-GC-MS to assess the fungal pretreatment efficiency for wheat straw anaerobic digestion
}

Elsa Rouches, Marie-France Dignac, Simeng Zhou, Hélène Carrère

\section{To cite this version:}

Elsa Rouches, Marie-France Dignac, Simeng Zhou, Hélène Carrère. Pyrolysis-GC-MS to assess the fungal pretreatment efficiency for wheat straw anaerobic digestion. Journal of Analytical and Applied Pyrolysis, 2017, 123, pp.409-418. 10.1016/j.jaap.2016.10.012 . hal-01506644

\section{HAL Id: hal-01506644 \\ https://hal.science/hal-01506644}

Submitted on 26 Sep 2017

HAL is a multi-disciplinary open access archive for the deposit and dissemination of scientific research documents, whether they are published or not. The documents may come from teaching and research institutions in France or abroad, or from public or private research centers.
L'archive ouverte pluridisciplinaire HAL, est destinée au dépôt et à la diffusion de documents scientifiques de niveau recherche, publiés ou non, émanant des établissements d'enseignement et de recherche français ou étrangers, des laboratoires publics ou privés. 


\section{Accepted Manuscript}

Title: Pyrolysis-GC-MS to assess the fungal pretreatment efficiency for wheat straw anaerobic digestion

Author: Elsa Rouches Marie-France Dignac Hélène Carrere

PII: $\quad$ S0165-2370(16)30347-3

DOI: $\quad$ http://dx.doi.org/doi:10.1016/j.jaap.2016.10.012

Reference: $\quad$ JAAP 3847

To appear in: $\quad$ J. Anal. Appl. Pyrolysis

Received date: $\quad$ 1-7-2016

Revised date: $\quad$ 13-10-2016

Accepted date: $\quad$ 13-10-2016

Please cite this article as: Elsa Rouches, Marie-France Dignac, Hélène Carrere, Pyrolysis-GC-MS to assess the fungal pretreatment efficiency for wheat straw anaerobic digestion, Journal of Analytical and Applied Pyrolysis http://dx.doi.org/10.1016/j.jaap.2016.10.012

This is a PDF file of an unedited manuscript that has been accepted for publication. As a service to our customers we are providing this early version of the manuscript. The manuscript will undergo copyediting, typesetting, and review of the resulting proof before it is published in its final form. Please note that during the production process errors may be discovered which could affect the content, and all legal disclaimers that apply to the journal pertain. 


\title{
Pyrolysis-GC-MS to assess the fungal pretreatment efficiency for wheat straw anaerobic digestion
}

\author{
Elsa Rouches ${ }^{a}$, Marie-France Dignac ${ }^{b}$, Hélène Carrere ${ }^{a *}$

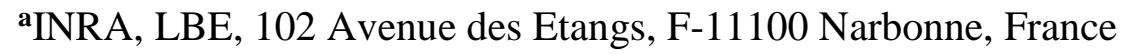 \\ 'bINRA, UMR1402 ECOSYS, F-78850 Thiverval-Grignon, France \\ *Corresponding author. Tel: +334 684251 68; Email address: \\ helene.carrere@supagro.inra.fr
}

Highlights

- High protein and carbohydrate amounts in mycelium of P. brumalis BRFM 985

- Suitability of Py-GC-MS to study S/G ratio

- Fungal biomass amount on WRF pretreated straws estimated by Py-GC-MS

- Pretreatment efficiency linked to polysaccharides/lignin ratio determined by Py-GCMS

- Py-GC-MS polysaccharides/lignin ratio may allow efficient strain selection

\begin{abstract}
Cost-effective and environment-friendly pretreatments, such as fungal pretreatments, are required for anaerobic digestion of lignocellulosic biomass particularly because the amount of methane production is often limited by the lignin content. Anaerobic digestibility is estimated using a Biochemical Methane Potential (BMP) test, which lasts several weeks. Since the PyGC-MS technique is considered to be a rapid method for obtaining information on various organic components, its suitability for the study of fungal pretreatment efficiency in anaerobic digestion was investigated here, to our knowledge for the first time. In this goal, mycelium of the white-rot fungi Polyporus brumalis BRFM 985, untreated wheat straw and straw pretreated with different fungal strains and under different conditions were analysed with PyGC-MS. In the mycelium pyrolysate, diverse compounds, often considered as unspecific, probably derive from proteins. A strong presence of tyrosine and phenylalanine among the fungus amino acids was also suspected.
\end{abstract}


As for pretreated straw samples, a correlation was observed between the amount of fungal biomass determined by qPCR (used as a reference method) and the sum of relative areas of toluene, styrene and ethylbenzene in the pyrograms, showing that it is feasible to estimate the fungal biomass amount on pretreated straws using Py-GC-MS.

In addition, the H/L-Py (Holocelluloses/Lignin) ratio, determined by dividing the sums of areas of pyrolysis compounds that have a polysaccharide (PS) and lignin (LIG) origin, was correlated to the BMP values of pretreated straws, thus showing that the pretreatment efficiency can be rapidly estimated with Py-GC-MS in the tested conditions.

\section{Abbreviations}

2w: two weeks (pretreatment duration)

ANOVA: ANalysis Of Variance

BMP: Biochemical Methane Potential

BRF: Brown-Rot Fungi

BRFM: Banque de Ressources Fongiques de Marseille, Marseille Bank of Fungal Ressources

Ev. ElectronVolt

GC: Gas Chromatography

H/L: Holocelluloses/Lignin

HSD: Honest Significant Difference

NBO: NitroBenzene Oxidation

LIG: Lignin

MS: Mass Spectrophotometry

N. A.: Not Available

PCA: Principal Component Analysis

PS: Polysaccharides

Py: Pyrolysis

Py-GC-MS: Pyrolysis-Gas Chromatography-Mass Spectrophotometry

RT: Retention Time

S. D.: Standard-Deviation

SSF: Solid-State Fermentation

TS: Total Solids

UWS: Untreated Wheat Straw

VS: Volatile Solids

WRF: White-Rot Fungi 
Biogas; fungal pretreatment; lignocellulosic biomass; solid state fermentation; delignification; biochemical methane potential;

\section{Introduction}

To face current challenges such as global warming, fossil fuel depletion and an increasing world population, second generation biorefineries are being developed. They are based on non-edible lignocellulosic substrates [1] that notably allow a greater net generation of energy per area of land [2]. Crop residues, in particular, limit the competition for land use with food. Among them, wheat straw is particularly available worldwide and can be considered as an experimental model [3].

However, the presence of lignin in such residues limits the yield of renewable fuels such as bioethanol or biogas [4,5]. A pretreatment step is required with lignin hydrolysis as main goal $[5,6]$. This step must also preserve the amount of carbohydrates since they are the substrate in the conversion to renewable fuels. Diverse non-biological pretreatments are effective [7] but costly (e. g. high energy consumption...) and can generate large amounts of waste (chemicals...).Biological pretreatment with lignin-degrading microorganisms have therefore become the object of renewed interest as they do not present these abovementioned disadvantages. White-rot Fungi (WRF), wood degrading fungi, are considered to be the most efficient organisms for delignification [5,8].

To ensure their growth on lignocellulosic substrates, WRF consume carbohydrates from holocelluloses (hemicelluloses and cellulose). Notwithstanding, some of them are considered as selective since they lead to significant lignin losses with little carbohydrate consumption. Fungal pretreatment efficiency is strain and substrate dependent, however culture conditions also play a major role in selective delignification [5].

This study focuses on fungal pretreatment for biogas production by anaerobic digestion. Anaerobic digestion is considered to be one of the most efficient ways to produce fuel and to manage waste $[9,10]$. During anaerobic digestion of lignocellulosic biomass, not only is cellulose converted to methane but so are hemicelluloses. In particular, methane production from lignocellulosic biomass can be predicted using the biomass content in lignin and 
crystalline cellulose (negative impact), amorphous holocelluloses and protein (positive impact) [11]. Cellulose crystallinity is often reduced during WRF pretreatment that positively affects anaerobic digestion. The protein content may increase due to the presence of the mycelium although variations are generally moderate [8]. Consequently, the Holocelluloses/Lignin (H/L) ratio appears to be a suitable indicator of the pretreatment efficiency for anaerobic digestion. Measurement of the S/G (synapyl /guaiacyl) ratio can also be helpful in the study of anaerobic digestibility. Indeed, the S/G ratio influences lignin degradability because G-units are generally less degradable than S-units [7].

Several techniques such as Nuclear Magnetic Resonance (NMR) or thioacidolysis are used to chemically characterize lignocellulosic biomass. They can be very expensive to run, they require users with expertise (NMR) or can be time consuming (several hours to prepare an analysable extract for thioacidolysis). Pyrolysis-Gas Chromatography-Mass Spectrophotometry (Py-GC-MS) has proven to be a useful tool because it hardly requires sample manipulation, while providing data on different compounds (carbohydrates, protein, lignin...) [12]. Moreover, the time of analysis is short compared to other existing methods [13].

A good estimation of the main components of lignocellulose can be obtained from certain quantitative methods; however different methods tend to produce different results. This is partly due to the difficulty in isolating pure fractions (protein residues in lignin fraction, etc.) [14], and for pyrolysis, in the incomplete release of analysable fragments. Although pyrolysis is generally a semi-quantitative method, the use of internal standard remains feasible [13]. However, for the analysis of samples with a large range of lignin contents, a correlation between Klason lignin and lignin estimated by pyrolysis for wood, grass and crop residues could be established without internal standard $[13,15,16]$. Py-GC-MS is considered as a sensitive, rapid and reproducible technique with almost no waste generation [17].

Some compounds formed by Py-GC-MS are known to originate specifically from lignin, polysaccharides, proteins, etc. [18]. Py-GC-MS of lignocellulose was successfully applied to study relative amounts of lignin and carbohydrates, to classify lignin based on their S/G ratio, to follow chemical changes in cell walls during plant maturation or after chemical or biological delignification. Finally, this technique was used to evaluate the origin and composition of food and feed, forest litter, compost and materials from the paper industry (pulps, papers, effluents) [17]. 
Few studies have applied Py-GC-MS on WRF pretreated wheat straw [17,19,20] or other lignocellulosic biomasses such as corn stover [21,22] or spruce [23] but it is noteworthy that in reflecting the chemical diversity of plants, pyrolysate composition is substratedependent.[24-26]. Nevertheless, none of these studies is linked to anaerobic digestion, except for one carried out by Liang et al. where anaerobic digestion of rice straw was evaluated as a pretreatment for Py-GC-MS [27]. To our knowledge, Py-GC-MS has not been applied to investigate the efficiency of fungal pretreatment for anaerobic digestion of lignocellulosic biomass. Therefore the application potential of this technique does not yet seem to be fully exploited. In particular, estimation of the amount of fungal biomass with PyGC-MS would be worthwhile in order to control fungal growth during pretreatment. In addition, as fungi are easily degraded during anaerobic digestion, the amount of fungal biomass may positively affect methane production from fungal pretreated substrate. The viable and rapid measurement of fungal biomass for different strains and culture conditions is often difficult to achieve [28].

The aim of this study was to investigate the suitability of Py-GC-MS to assess the anaerobic biodegradability of wheat straw pretreated by several fungal strains (five WRF and one Brown-Rot Fungi (BRF)). Firstly, mycelium of a white-rot fungus, fungal treated and untreated straw were analysed with Py-GC-MS and their pyrolysates were described. Secondly, relationships between pyrolysis data, other characterization results and anaerobic degradability were evaluated.

\section{Material and methods}

\subsection{Sample preparation}

\subsubsection{Fungal strains and straw substrate}

Winter wheat straw (Triticum aestivum) was obtained from Vivescia (Reims, France). It was harvested in the North of France in 2012.

As previously described by Zhou et al. [28], basidiomycete strains used in this study belong to the "Centre International de Ressources Microbiennes" dedicated to filamentous fungi of biotechnological interest (CIRM-CF) and maintained at the French National Institute of Agricultural Research (INRA; Marseille, France). Efficient WRF strains [29,30] were used to 
pretreat straw for anaerobic digestion (Table 1). An inefficient Brown-Rot Fungi (Gloeophyllum trabeum BRFM 236) [30] was used for comparison.

\subsubsection{Cultivation of Polyporus brumalis BRFM 985 on liquid medium}

Mycelium of Polyporus brumalis BRFM 985 was cultivated on liquid medium (malt broth extract $20 \mathrm{~g} / \mathrm{L}$ ) in Roux flasks plugged with cotton wool. All materials and culture medium were autoclaved for $20 \mathrm{~min}$ at $120^{\circ} \mathrm{C}$. Inoculation was performed with five agar discs $(5-\mathrm{mm}$ diameter) of 7-day old mycelia. After 10 days at $30^{\circ} \mathrm{C}$, mycelium was harvested, washed extensively with ultra-pure water and freeze-dried.

\subsubsection{Fungal pretreatment}

As previously described [29], fungal pretreatments were carried out in glass columns which contained $20 \mathrm{~g}$ total solids (TS) of autoclaved ground wheat straw (4 mm), $25 \mathrm{mg}$ of glucose/g Total Solid (TS) and $2.5 \mathrm{mg}$ of tartrate diammonium/g TS. Column temperatures were set to $28^{\circ} \mathrm{C}$. Airflow saturated with moisture was set to $120 \mathrm{~mL} / \mathrm{min}$, measured by a ball flowmeter. For each strain, cultures in Solid-State Fermentation (SSF) columns were triplicated and the resulting pretreated wheat straws were homogenized. Culture duration lasted three weeks for all samples. However, for two strains, BRFM 985 and BRFM 1554, a second culture duration of two weeks was tested (suffix ' $-2 \mathrm{w}$ ' added to the BRFM number for the identification of corresponding samples in Table 1). These two samples were inoculated with $130 \mathrm{mg}$ (dry weight) ground mycelium whereas others received $120 \mathrm{mg}$ (dry weight). At the beginning of the cultivation, straw was moistened: wet straw weight (WW) corresponded to 4.5 fold the initial TS weight for samples pretreated during three weeks and 4.25 for samples pretreated during two weeks. Samples (Table 1) were identified with their BRFM number in Py-GC-MS results. Few samples issued from further pretreatment with the efficient strain Polyporus brumalis BRFM 985 were also characterized with Py-GC-MS. These samples (Table 1), corresponding to various culture conditions, were identified by a number preceded by the letter "C". During the inoculation step, some of them received a metal solution composed of $\mathrm{MnSO}_{4} ; \mathrm{CuSO}_{4}$ and $\mathrm{FeSO}_{4}$ at $18 \mathrm{mM}$ each. Three culture temperatures $\left(20^{\circ} \mathrm{C}, 25^{\circ} \mathrm{C}, 30^{\circ} \mathrm{C}\right)$, two culture durations (12.5 or $17.5 \mathrm{~d}$ ) and four initial Wet Weights (WW) were used. After pretreatment, samples were freeze-dried.

Table 1. Strains and pretreatment conditions for straw samples analysed with Py-GC-MS and their BMP. N. A.: Not Available. 


\subsection{Pyrolysis-Gas Chromatography-Mass Spectrophotometry}

\subsubsection{Analytical conditions}

Prior to Py-GC-MS analysis, samples were ground in a ball mill for 5 min at $25 \mathrm{~Hz}$ (Mix Mill 400 , Retsch). Straws pretreated with various strains (Table 1), with a culture duration of 3 or 2 weeks (' $-2 \mathrm{w}$ ') and an untreated straw (UWS) were analysed by Py-GC-MS in triplicate. The typical standard deviation of their relative chromatographic peak areas was about $30 \%$ on average for compounds retained for further analysis. Mycelium of BRFM 985 was also studied. The mycelium sample was only analysed once since it was considered as more homogeneous.

Approximately $0.5-1 \mathrm{mg}$ of sample were loaded in a quartz tube closed with quartz wool and heated up to $650^{\circ} \mathrm{C}$ within $0.15 \mathrm{~s}$ (30 s hold) using a pyrolysis unit (CDS Pyroprobe 5000 Series). The pyrolysis products were transferred through a transfer line maintained at $280^{\circ} \mathrm{C}$ for 15 min towards the Hewlett Packard HP-6890 gas chromatograph (GC) split/splitless injector. The injector was equipped with a straight liner, operated in splitless mode and maintained at $280^{\circ} \mathrm{C}$.

The GC was equipped with a $60 \mathrm{~m}$ fused silica capillary column SolGelWax (SGE, $0.32 \mathrm{~mm}$ i.d., film thickness $0.5 \mu \mathrm{m})$, with helium as carrier gas $(1 \mathrm{~mL} / \mathrm{min})$.

The temperature program of the GC oven was set to increase the temperature from 30 to $280^{\circ} \mathrm{C}$ at $2^{\circ} \mathrm{C} / \mathrm{min}$. The compounds were identified with an HP-5973 Electron ionization mass spectrometer (MS) used in the scan mode (70 eV, scan range m/z 40-700, $1.2 \mathrm{scan} / \mathrm{s})$.

\subsubsection{Analysis and interpretation of pyrograms}

Compounds in pyrolysates were identified on the basis of their GC retention times and mass spectra compared to Wiley library and published mass spectra. Peaks were integrated using the HP MS Chemstation (Version C.01.05). The total ion current signal was used for integration. All pyrograms were normalized with the same peak height of the compound phenol, 2,6-dimethoxy- (coded LIG6-S). Relative areas, calculated by the software with manual verification, and expressed per thousand of total areas were estimated for each molecule. Then, an average of the relative areas for triplicates was calculated. For some compounds, only two values of the relative areas were obtained, either because the compound was not present in one replicate, or because it had coeluted with another compound. 
Samples resulting from the optimization step (samples identified with letter "C") were extrasamples collected to improve correlation robustness. For those samples, only a few compounds were integrated by the software with manual verification. However, to calculate the Holocelluloses $(\mathrm{H}) /$ Lignin $(\mathrm{L})$ ratio, all compounds identified automatically with a quality greater than $60 \%$ (as estimated by the software comparing library and measured mass spectra) were automatically integrated.

\subsection{Characterization of fungal pretreated straws for anaerobic digestion}

\subsubsection{Acid hydrolysis (Klason lignin, cellulose and hemicelluloses) with NREL method}

As previously described by Zhou [31], the analysis of lignin, cellulose and hemicellulose contents was carried out according to a modified NREL two-stage acid hydrolysis method [32]. The released reducing sugars and glucose were quantified respectively using the dinitrosalicylic acid method (DNS) and the glucose RTU kit (Biomérieux, Marcy-l'étoile, France). Xylose (major hemicelluloses component in wheat straw) was estimated as the difference between reducing sugars and glucose.

\subsubsection{Fungal biomass quantification by qPCR}

Fungal biomass was quantified with qPCR for all samples pretreated with different strains (except 1296) and for a few samples produced by the optimization of P. brumalis BRFM 985 cultivation (C1, C2, C9) according the methodology established by Zhou et al. [28] . Standard curves were established for each strain using serial dilutions of genomic DNA.

\subsubsection{VS and TS determination}

For each substrate and for the inoculum of anaerobic digestion, TS and VS were measured according to Standard Methods [33].

\subsubsection{BMP-tests}

BMP tests methodology was the same as already described [29]. They were carried out in three series: samples pretreated for 21 days, samples pretreated for 14 days (985-2w and 1554-2w) and samples pretreated by BRFM 985 with diverse culture conditions noted C in Table 1. 


\subsection{Statistical analysis}

\subsubsection{Analysis of Variances (ANOVA)}

Analysis of variance (ANOVA, $\alpha=0.05$ ) was carried out using the $\mathrm{R}$ software (version 3.2.1) with "lattice" and "lawstat" libraries. Multiple mean comparisons were performed with Tukey's HSD (Honest Significant Difference) test at the same significance threshold of 0.05. ANOVA was used to compare S/G ratio. Samples 1048 and 1554 were excluded due to their high standard deviation considering the three obtained values for this variable.

\subsubsection{Principal Component Analysis (PCA)}

Principal Component Analysis (PCA) was built with the SIMCA software from UMETRICS. The number of components is determined automatically (being based on the Kaiser criterion). The quality of representation for individuals (samples) is based on the $\operatorname{Dmod}_{\mathrm{x}}$ representing the distance between the sample and the model in the X-space (space defined by variables on a retained component). Dmod ${ }_{x}$ is expressed in normalized units when divided by the residual standard deviation of a sample to the model. Given that the statistical distribution is known (F-distribution), the software plots a chart that can be employed for the detection of moderate outliers [34].Due to numerous missing values in the set of pyrolysis data (due to limit of detection, co-elution, etc.), only pyrolysis compounds which had an estimable relative area for more than half of the samples were taken into account. Several variables influencing the BMP were studied: fungal biomass determined by qPCR (qPCR on PCA, expressed in $\mathrm{mg} / \mathrm{g}$ straw), Klason lignin (LIG), hemicelluloses (HEMI) and cellulose (CEL) determined by NREL method (expressed in \% TS) and the resulting H/L (H/L-NREL) and finally, H/L obtained with Py-GC-MS (H/L-Py). BMP values were also included as variable to build the PCA (expressed in $\mathrm{NmL} / \mathrm{g}$ VS). On three axes, $75 \%$ of the whole information contained in data is expressed with the PCA.

\section{Results and discussion}

\subsection{Origin of the main pyrolysis products}

Compounds observed in the pyrolysates were classified into three groups of compounds characterised by a specific origin: polysaccharide-derived products (PS), N-containing compounds (N) and lignin-derived products (LIG). Another group was used for compounds with an unspecified origin (UN) which can be formed from several sources during pyrolysis. The code attributed to the main chemical compounds identified in pyrolysates is composed of 
an abbreviation of the origin (PS, N, LIG or UN) followed by a number. Finally, compounds with an unknown origin were just numbered: e. g. 64 for ethylbenzene and 66 for xylene. Identified pyrolysis products and their relative areas (per thousand of the total area of identified peaks) for straw samples are reported in Table 2 and arranged according to their retention times (RT) and class origin. Basic statistics (mean, standard-deviation, etc.) were also calculated in order to better identify compounds that may be subject to variations related to culture conditions. Table 2 shows the products identified in pyrolysates of untreated straw and straw pretreated with various strains whereas Table 3 shows main pyrolysis compounds for Polyporus brumalis BRFM 985 fungus and straw samples pretreated with this strain in various conditions.

Table 2. Product identification from untreated wheat straw (UWS) and fungal pretreated straws with several strains (identified by their BRFM number) and their average relative areas per thousand and sums, ranged by increased retention time (RT) and per compound class (LIG, N, PS, UN) as found in literature. In this table, only peak areas equal to zero represent the absence of a compound, empty cells only mean a difficulty to identify the compound (coelution, peak too small or absent). ${ }^{1}$ grey cells show $\mathrm{SD} /$ mean $>50 \% ;{ }^{2}$ grey cells show compounds detected in less than 4/9 samples; SD: Standard-deviation.

Table 3. Average relative areas for triplicates ranged per pyrolysis compounds for samples from the optimization step (samples pretreated BRFM 985 strain in various conditions) with and Polyporus brumalis BRFM 985 mycelium pyrolysate.

\subsubsection{Fungus sample}

The pyrogram of the mycelium of Polyporus brumalis BRFM 985 is presented in Fig.1. It is dominated by molecules with a polysaccharide origin (PS). Several N-containing compounds are also identified $(\mathrm{N})$; they can either originate from protein or from chitin $[18,35]$. Chitin is specific to fungi and arthropod invertebrates. It is a polymer of $\mathrm{N}$-acetylglucosamine with a similar structure to glucose but comprising an $\mathrm{N}$-acetyl group instead of the hydroxy methyl 
group. The amount of chitin in wood decaying fungi is variable, e. g. ranging from $3 \%$ to $27 \%$ of the dry cell-wall [36].

The pyrogram of $P$. brumalis BRFM 985 is dominated by carbohydrates and proteins, in agreement with the fungal composition proposed in the literature, [37,38].

Fig. 1. Pyrogram of mycelium of Polyporus brumalis BRFM 985. Compound codes are reported in Table 2 except for N5, N6 and N8 that correspond to pyridine, 3-methyl; pyridine, 2-methyl-; 1H-pyrrole, 2-methyl-, respectively.

\subsubsection{N-containing (N) and unspecific compounds (UN)}

The most likely origin for N-containing compounds found in the mycelium pyrogram (Fig.1) was investigated. pyridine (N4, N5) can derive from alanine-containing proteins but also from chitin pyrolysis [35].

Indoles (N1, N2) probably originate from a tryptophan in the fungus pyrolysate. Pyrrole (N8) can either have a protein origin (hydroxyproline, proline, glycine and glutamic acid) or a pigment origin [18]. Given the fact that pigments are minor compounds in fungi [37], protein is the most likely origin.

Toluene (UN1), 4-methyl phenol (UN6) and phenol (UN5) are considered as unspecific (UN) because, apart from their protein origin, they can also represent minor peaks in lignin or tannin pyrograms [18]. A lignin or tannin origin is unlikely for this fungus sample. Toluene (UN1) can also have a PS-origin [15] and was detected in xylan fractions [39]. Phenol (UN5) and 4-methyl phenol (UN6) were minor compounds of cellulose or xylan pyrolysates [40], but their polysaccharide origin was not strongly established. They have been identified in oat spelt xylan pyrolysate, but they may also originate from the presence of lignin impurities in the isolated xylan, notably due to the strong hemicellulose-lignin linkages that lead to a difficult isolation of the pure xylan fraction [7,41]. Consequently, in the mycelium pyrolysate, toluene (UN1), 4-methyl phenol (UN6) and phenol (UN5) are considered to originate mainly from proteins.

The origin of styrene (UN2) is generally unspecific [18]. A significant contribution has been found after pyrolysis of BRFM 985 mycelium. Apart from proteins, other possible origins for styrene (UN2) are p-coumaric or ferulic acids, lignin or tannins [18,42]. Since these 
molecules are not major fungal compounds, a protein origin (phenylalanine) is also favoured in the mycelium pyrolysate. Phenylalanine pyrolysis leads to a high toluene (UN1) peak, a medium styrene (UN2) peak and a small ethylbenzene (64) peak [43], which corresponds to the distribution of these three peaks in the fungus pyrolysate (Fig.1).They therefore very likely indicate the presence of a high amount of phenylalanine in the mycelium. A tyrosine origin can be suggested for 4-methyl phenol (UN6) and phenol (UN5). UN1, UN2, UN5 and UN6 presented major peaks in the fungus pyrolysate. Therefore, phenylalanine and tyrosine could represent major amino acids in $P$. brumalis BRFM 985 mycelium.

The presence of these amino acids in fungi has already been noticed in high quantities along with threonine in the WRF Lentinus tigrinus [44] whereas histidine, aspartic and glutamic acids were main amino acids in the WRF Pleurotus ostreatus mycelium [45]. Nevertheless, amino acid composition remains strain and substrate dependent but also depends on culture conditions [46].

\subsubsection{Polysaccharide-derived products (PS)}

Major peaks derived from polysaccharides in fungus pyrolysate (Fig.1) are most likely issued from glucose polymers: furan, 2-methyl (PS28), 1,4:3,6-dianhydro- $\alpha$-D-glucopyranose (PS21), furan, 2,5-dimethyl- (PS35), 2-cyclopenten-1-one, 2-hydroxy-3-methyl- (PS34) and 2-cyclopenten-1-one, 2,3-dimethyl- (PS8). These products can effectively be encountered in cellulose pyrolysates $[47,48]$. Some of them have also been reported in other kinds of glucose polymers: in particular, PS21 can be found in 1-3 branched glucan pyrolysates. Glucose polymers constitute an important part of fungi polysaccharides. They can prevail as glycogen and trehalose (storage function) or hyphal linked glucans excreted by fungi [49-51]. PS28 can originate from chitin, while the minor 2-furancarboxaldehyde, 5-methyl- (PS9) peak can derive from glycogen [52,53].

Finally, mannitol has also been described as a major carbohydrate in fungi $[53,54]$ although no mannitol specific products have been observed after pyrolysis of $P$. brumalis BRFM 985 mycelium. The maltol (PS36) peak does not derive from mannitol [55] but from glucose polymers as it has been reported in cellulose pyrolysis [47].

Compounds observed in the $P$. brumalis pyrolysate are not specific to this strain and can be observed in other fungal groups as well. For instance, in the pyrolysate of the stone 
deteriorating fungi Ulocladium atrum (not WRF), diverse compounds similar to those observed in $P$. brumalis pyrolysate were also found in significant amounts: toluene (UN1), methylfuran (PS28), 1,4:3,6-dianhydro- $\alpha$-D-glucopyranose (PS21), dimethylfuran (PS35). Styrene (UN2) and phenol (UN5) also showed a moderate contribution [49].

\subsubsection{Straw characterization}

The pyrograms of untreated straw and straw pretreated with Trametes ljubarskii BRFM 957 strain, as an example, are presented in Fig. 2. Data from pyrograms of straw pretreated with other strains are summarized in Tables 2 and 3. Given the three main constituents of wheat straw (cellulose, hemicelluloses (carbohydrates) and lignin (polyphenols) [56]), straw pyrograms were dominated, as expected, by lignin- and polysaccharide-derived compounds.

Fig. 2. Pyrogram of (a) untreated wheat straw (UWS) and (b) fungal treated straw with Trametes ljubarskii BRFM 957 strain. Compound codes are reported in Table 2.

\subsubsection{Lignin-derived pyrolysis products}

Lignin-derived pyrolysis products dominated pyrolysates of wheat straws (Fig. 2), as previously observed by Reeves and Galletti [57]. Lignin is formed by an association of three monolignols: p-hydroxyphenyl (H, no methoxy substituent), guaiacyl (G, one methoxy substituent) and syringyl (S, two methoxy substituents) units. Pyrolysis products were labelled according to their origin: S- and G-units derived compounds are classified as LIG-S and LIG-G, respectively (Table 2). Compounds derived from $\mathrm{H}$-units in the pyrograms are often considered as unspecific, especially because they can also originate from cinnamic acids (not lignin units) which are frequent in non-woody-plants [50, 16]. In addition, H-units are less abundant in grass compared to S- and G-units [16]. For these reasons, H-units have not been considered in the current study.

Major peaks in untreated straw pyrolysates (Fig. 2a) were guaiacol (LIG1-G), phenol, 2,6dimethoxy- (LIG6-S) and 2-methoxy-4-vinylphenol (UN13). Guaiacol (LIG1-G) and/or 2methoxy-4-vinylphenol (UN13) have already been reported as major compounds in untreated wheat straw, unlike phenol, 2,6-dimethoxy- (LIG6-S), even though the latter is generally present in wheat straw pyrolysates [15,19,57]. However, Camarero et al. [19] have observed a major peak of 4-vinyl-2,6-dimethoxyphenol whose chemical structure is close to LIG6-S. 
2-methoxy-4-vinylphenol (UN13) was classified as an unspecific compound since it has been identified in lignin samples but also in small amounts in xylan samples. Nonetheless, the lignin origin is favoured [18] because, as noted above, lignin residues can also be found in xylan fractions. The methyl guaiacol (LIG2-G) peak is quite large in untreated straw pyrolysates, while vanillin (LIG22-G) is a minor peak (Fig. 2a). High amounts of methyl guaiacol (LIG2-G) were observed in lignin isolated from maize [59], and associated with vanillin (LIG22-G), they were both major compounds of pyrolyzed milled wood lignin [60].

The pyrolysis results obtained in this study on wheat straw are thus consistent with previously published characterizations, although some differences can be noted in the distribution of lignin-derived pyrolysis products. Yield and composition of pyrolysates can vary, particularly due to the diversity of Py-GC-MS operating conditions (heating rates, temperatures...) [61]. Moreover, even within a same species, lignocellulosic samples are known to vary in their composition (growth stage, tissue...).

\subsubsection{Polysaccharide-derived products}

Unsurprisingly, polysaccharide-derived pyrolysis products are abundant in wheat straw pyrolysates. They can originate from cellulose and hemicelluloses, which are major constituents of lignocellulosic biomass. Cellulose is a polymer of glucose whereas wheat straw hemicelluloses are mainly composed of xylan with other minor carbohydrates (glucose...). Major polysaccharide-derived compounds observed in straw pyrolysates are 1,2cyclopentanedione (PS30), 1,2-cyclopentanedione, 3-methyl- (PS16) and furfural (PS25) (Fig. 2). Furfural (PS25) was reported as a major compound of crop pyrolysates (including wheat straw) by Ross and Mazza [15]. They also reported PS16 in wheat straw pyrolysates. These major polysaccharide-derived compounds (PS30, PS16 and PS25) were not observed in the mycelium pyrolysate (Fig. 1). In contrast, some polysaccharide-derived compounds of straw pyrolysates, such as furan, 2-methyl (PS28), 1,4:3,6-dianhydro- $\alpha$-D-glucopyranose (PS21), 2,5-dimethyl- furan (PS35) have also been detected in fungus pyrolysates.

Only a few PS-derived compounds can be assigned to a specific carbohydrate origin (glucose, xylose...). The 1,4:3,6-dianhydro- $\alpha$-D-glucopyranose (PS21) compound specifically derives from glucose polymers [18] and has been found in both fungus and straw pyrolysates (as expected). No specific compounds from hemicelluloses were identified in the current study, thus polysaccharides originating from fungus cannot be well distinguished from those derived from straws with pyrolysis. 


\subsubsection{N-containing compounds}

Only one N-containing compound was observed (in sample 1554-2w). This N-containing compound, pyridine (N4), originated from protein or chitin. The low contribution of $\mathrm{N}$ containing products can be explained by the low protein content of wheat straw (around $3 \%$ ) [62] and also by the low amount of fungal biomass on pretreated straw.

\subsection{Link between Py-GC-MS data and other characterization techniques and the anaerobic digestibility of straw}

Cellulose and hemicelluloses are converted into methane during anaerobic digestion. Lignin, with its protective role in plants, is recalcitrant to anaerobic degradation [56]. Anaerobic digestibility is most often measured by a BMP-test that consists in digesting a substrate under optimal conditions. The result of this test is the BMP value (Table 1), the maximum quantity of methane produced per amount of substrate after its complete biodegradation. However, with slowly biodegradable substrates such as straw, several months can be required to reach the BMP value. The characterization of the composition of fungal pretreated wheat straws helps to rapidly estimate the pretreatment efficiency for anaerobic digestion. An efficient pretreatment is characterised by a significant decrease in the lignin content of pretreated straw compared to untreated straw as well as a limited loss in carbohydrates. In order to evaluate the relevance of using Py-GC-MS to characterize fungal pretreated straw for anaerobic digestion, the pyrolysis results were compared to results obtained with other characterization techniques.

Identified pyrolysis products originating from polysaccharides and lignin, in particular lignin $\mathrm{G}$ and $\mathrm{S}$, are displayed in Table 2. Sums of average relative areas were calculated for chosen groups of compounds (holocelluloses H, lignin L, lignin G and S, etc.). The contribution of lignin-derived compounds in pyrolysates (percentage of lignin-derived products) is calculated using the sum of relative areas of lignin-derived compounds divided by the sum of the relative areas of all compounds. This quantitative overview of main compounds in pyrolysates is reported in supplementary material (Table S1). Pyrolysis results for the BRFM 1048 sample have not been discussed since the standard deviations for this sample are particularly high $(\mathrm{H} / \mathrm{L}-\mathrm{Py}=8 \pm 8)$. 


\subsubsection{Variations of the $S / G$ ratio}

S/G estimated with Py-GC-MS ranged between 0.5 and 0.6 in most samples (Table S1, supplementary material). Similar results were found after wheat straw Py-GC-MS even if slightly different analytical conditions were used (pyrolysis temperature, etc.) among studies $[63,64]$.

Several studies have pointed to a lack of correlation between $S / G$ ratios estimated with chemical methods and with Py-GC-MS. The S/G ratios of lignin can be estimated by various chemical methods, the most commonly used being nitrobenzene oxidation (NBO), cupric oxidation and thioacidolysis $[19,65,66]$. Other techniques such as ${ }^{13} \mathrm{C}$ Nuclear Magnetic Resonance (NMR) can also be used but do not seem to be well adapted for S/G determination in wheat straw [67]. Chemical methods break uncondensed bonds, mainly $\beta-\mathrm{O}-4$ ether bonds that are the main linkages in lignin [66]. By contrast, Py-GC-MS is capable of breaking certain C-C bounds (condensed) between lignin units [42,68]. G-units are more involved in condensed linkages than S-units [7,66]. Consequently, the estimation of G-units with Py-GCMS is higher when compared to other methods, thus decreasing the S/G ratio obtained with pyrolysis. S/G obtained with Py-GC-MS may be closer to the real value [15]. For wheat straw, the S/G ratio reached 0.8 when measured with NBO or cupric oxidation [69]; 0.9 with thioacidolysis [70] and 0.6 with Py-GC-MS. To obtain similar results between chemical and Py-GC-MS determinations of S/G ratio, either certain specific pyrolysis compounds can be selected [71,72] or alkaline lignin extraction would have to be carried out before Py-GC-MS [64].

\subsubsection{Fungal biomass (qPCR measurements)}

As explained in 3.1.1.1, high amounts of phenylalanine in the mycelium of BRFM 985 is suspected due to the presence of large UN1 and UN2 peaks as well as a small ethylbenzene peak (pyrolysis product 64) in fungus pyrolysate. UN1 and UN2 can be good indicators of fungal development as their relative areas are well correlated to fungal biomass, whether separately ( $\mathrm{R}^{2}=0.72$ for $\mathrm{UN} 1$ and $\mathrm{R}^{2}=0.68$ for $\left.\mathrm{UN} 2\right)$ or for their sum with compound 64 $\left(\mathrm{R}^{2}=0.81\right.$, Fig. 3$)$. Even though such a sum would lead to a more precise estimation of fungal biomass, the simple use of UN1 or UN2 is also possible in the case when some compounds are not present in the pyrograms,. Therefore, pyrolysis would allow the amount of WRF to be monitored during wheat straw pretreatment. 
Fig. 3. Fungal biomass amounts estimated with Py-GC-MS and qPCR. Linear correlation between the sum of relative areas of toluene (UN1), styrene (UN2) and ethylbenzene (64) (Py-GC-MS) and fungal biomass (qPCR). This graph is plotted with all samples measured with qPCR: 957, 985, 1048, 1554, 982-2w, 1554-2w, C1, C2 and C9.

\subsubsection{Variations in lignin and polysaccharide contents among straws}

The relative contributions of PS compounds increased in pyrolysates of treated straw in comparison to untreated straw (Table 2). It is likely that this increase could be due to lignin removal that leads proportionally to more carbohydrates in the pyrograms $[57,73]$. No linear correlation was obtained between $\mathrm{H} / \mathrm{L}$ ratios or lignin proportions obtained with the NREL method (acid hydrolysis) or Py-GC-MS (PCA in supplementary data). Indeed, as the structure of carbohydrate polymers is less stable compared to that of lignin, they are more readily fragmented during pyrolysis and thus produce many non-diagnostic low molecular weight compounds [42]. Consequently, estimation of the PS content relative to lignin with pyrolysis is often inaccurate. Lignin characteristics obtained with pyrolysis can depend on several parameters, such as the ash content of samples that can influence the yield in pyrolysis compounds $[16,40,74]$. With current samples, the maximum variation in ash contents between samples is relatively small (2\% TS more compared to UWS, data not shown). Studies evidencing a correlation between relative lignin contents determined with Py-GC-MS and with the NREL method used either a predictive statistical model (partial least squares according to Fahmi et al. [16]) or high variations in lignin contents and a high number of samples: i.e. about $15 \%$ for the lignin Klason variation according to Ross and Mazza [15] with 15 to 60 samples and about $10 \%$ for the lignin Klason variation according to Alves et al. [13] with 81 samples. In the current study, the most likely explanation for the mismatch $\left(\mathrm{R}^{2}=\right.$ 0.163 with data from Table 2 ) would be the lesser variation between samples ( $\approx 6 \%$ for lignin Klason) combined with a lower number of samples (8) compared to literature studies without predictive statistical model. Considering the mycelium sample (lignin amount close to zero) along with the pretreated samples to increase the lignin content variation, a slight correlation $\left(R^{2}=0.505\right)$ was observed between the relative lignin content determined with Py-GC-MS and the NREL method. 


\subsubsection{Biomethane potential (BMP)}

Despite the mismatch between H/L-Py and H/L-NREL, the slight correlations between H/LPy or to H/L-NREL and BMP (PCA in supplementary data) were displayed in Fig. 4. These correlations highlight the significance of the $\mathrm{H} / \mathrm{L}$ ratio for comparing fungal pretreated straws for anaerobic digestion applications: the higher the H/L ratio, the higher the BMP. It seems thus possible to use pyrolysis, in particular the H/L-Py ratio, to investigate pretreatment efficiency for anaerobic digestion.

Fig. 4. Correlation between BMP and H/L ratio determined with Py-GC-MS or the NREL method for straw samples. BMP versus H/L-Py is plotted with samples 236, 957, 985, 1296, 1554, C2, C9, C15, C17 and UWS. BMP versus H/L-NREL is plotted with samples 236, 957, 985, 1048, 1296, 1554, C1, C2, C9, C13, C15 and C17.

\section{Conclusion}

To our knowledge, for the first time a correlation has been observed between the amount of WRF fungal biomass determined by qPCR and the peak areas of a few compounds released by Py-GC-MS of pretreated wheat straws. In particular, these compounds include toluene and styrene, which are present in high amounts in mycelium pyrolysate. Therefore, Py-GC-MS allows for the estimation of WRF biomass growth on pretreated wheat straws.

Anaerobic digestibility of fungal pretreated wheat straws can be assessed by the determination of the H/L ratio with Py-GC-MS. Since different culture conditions have been applied in this study, it seems possible to use the pyrolysis $\mathrm{H} / \mathrm{L}$ ratio for the anaerobic degradability of wheat straw samples to be assessed using different fungal strains and slightly different fungal pretreatment conditions (such as culture temperatures varying between $25-30^{\circ} \mathrm{C}$ or culture durations between 12.5 and 21 days). This correlation still needs to be confirmed within a broader context which would require further measurements with more diverse pretreatment conditions. Indeed, Py-GC-MS could be a useful tool to pre-select efficient fungal strains for anaerobic digestion and to optimize pretreatment conditions on a chosen strain. 


\section{ACKNOWLEDGMENTS}

Authors are grateful to the ANR, National Research Agency, for financial support (project ANR-12-BIOME-009) STOCKACTIF. Authors acknowledge Simeng Zhou who provided the pretreated samples and some characterization analyses as well as Dr Anaïs Rancon for taking part in experimental work.

\section{REFERENCES}

[1] Frigon J-C, Guiot SR. Biomethane production from starch and lignocellulosic crops: a comparative review. Biofuels, Bioproducts and Biorefining 2010;4:447-58. doi:10.1002/bbb.

[2] Hallac BB, Sannigrahi P, Pu Y, Ray M, Murphy RJ, Ragauskas AJ. Biomass characterization of Buddleja davidii: a potential feedstock for biofuel production. Journal of Agricultural and Food Chemistry 2009;57:1275-81.

[3] Vassilev S V, Baxter D, Andersen LK, Vassileva CG. An overview of the chemical composition of biomass. Fuel 2010;89:913-33. doi:10.1016/j.fuel.2009.10.022.

[4] Chandler JA, Jewell WJ. Predicting methane fermentation biodegradability. Solar Energy Research Institute; 1980.

[5] Wan C, Li Y. Fungal pretreatment of lignocellulosic biomass. Biotechnology Advances 2012;30:1447-57. doi:10.1016/j.biotechadv.2012.03.003.

[6] Carrere H, Passos F, Antonopoulou G, Rouches E, Affes R, Battimelli A, et al. Enhancement of anaerobic digestion performance: which pretreatment for which waste? 5th International Conference on Engineering for Waste and Biomass Valorisation (WasteEng14), Rio de Janeiro: 2014.

[7] Monlau F, Barakat A, Trably E, Dumas C, Steyer JP, Carrère H. Lignocellulosic Materials Into Biohydrogen and Biomethane: Impact of Structural Features and Pretreatment. Critical Reviews in Environmental Science and Technology 2013;43:260-322.

[8] Rouches E, Herpoël-Gimbert I, Steyer JP, Carrere H. Improvement of anaerobic degradation by white-rot fungi pretreatment of lignocellulosic biomass: A review. Renewable \& Sustainable Energy Reviews 2016;59:179-98.

[9] Börjesson P, Mattiasson B. Biogas as a resource-efficient vehicle fuel. Trends in Biotechnology 2008;26:7-13. doi:10.1016/j.tibtech.2007.09.007.

[10] Ward AJ, Hobbs PJ, Holliman PJ, Jones DL. Optimisation of the anaerobic digestion of agricultural resources. Bioresource Technology 2008;99:7928-40. doi:10.1016/j.biortech.2008.02.044.

[11] Monlau F, Sambusiti C, Barakat A, Guo XM, Latrille E, Trably E, et al. Predictive models of biohydrogen and biomethane production based on the compositional and structural features of lignocellulosic materials. Environmental Science \& Technology 2012;46:12217-25. doi:10.1021/es303132t.

[12] Rodriguez J, Hernández-Coronado MJ, Hernandez M, Bocchini P, Galletti GC, Arias ME. Chemical characterization by pyrolysis/gas chromatography/mass spectrometry of acid-precipitable polymeric lignin (APPL) from wheat straw transformed by selected 
Streptomyces strains. Analytica Chimica Acta 1997;345:121-9.

[13] Alves A, Schwanninger M, Pereira H, Rodrigues J. Analytical pyrolysis as a direct method to determine the lignin content in wood: Part 1: Comparison of pyrolysis lignin with Klason lignin. Journal of Analytical and Applied Pyrolysis 2006;76:209-13. doi:10.1016/j.jaap.2005.11.004.

[14] Reeves JB, Francis B a. Pyrolysis-gas-chromatography-mass-spectrometry for the analysis of forages and by-products. Journal of Analytical and Applied Pyrolysis 1997;40-41:243-66. doi:10.1016/S0165-2370(97)00010-7.

[15] Ross K, Mazza G. Comparative Analysis of Pyrolysis Products from a Variety of Herbaceous Canadian Crop Residues 2011;7:763-76.

[16] Fahmi R, Bridgwater a. V., Thain SC, Donnison IS, Morris PM, Yates N. Prediction of Klason lignin and lignin thermal degradation products by Py-GC/MS in a collection of Lolium and Festuca grasses. Journal of Analytical and Applied Pyrolysis 2007;80:1623. doi:10.1016/j.jaap.2006.12.018.

[17] Galletti GC, Bocchini P. Pyrolysis/gas chromatography/mass spectrometry in lignocellulose. Rapid Communication in Mass Spectrometry 1995;9:815-26.

[18] Dignac M-F, Houot S, Francou C, Derenne S. Pyrolytic study of compost and waste organic matter. Organic Geochemistry 2005;36:1054-71. doi:10.1016/j.orggeochem.2005.02.007.

[19] Camarero S, Galletti GC, Martinez a. T. Preferential degradation of phenolic lignin units by two white rot fungi. Applied and Environmental Microbiology 1994;60:450916.

[20] Zeng J, Singh D, Chen S. Biological pretreatment of wheat straw by Phanerochaete chrysosporium supplemented with inorganic salts. Bioresource Technology 2011;102:3206-14. doi:10.1016/j.biortech.2010.11.008.

[21] Yang X, Laskar DD, Ma F, Zhang X, Chen S. Medium-Temperature Pyrolysis of Corn Stover Improved by Biopretreatment with White-rot Fungi. Bioressources 2013;8:6383-94.

[22] Yang X, Ma F, Yu H, Zhang X, Chen S. Effects of biopretreatment of corn stover with white-rot fungus on low-temperature pyrolysis products. Bioresource Technology 2011;102:3498-503. doi:10.1016/j.biortech.2010.11.021.

[23] Vane $\mathrm{CH}$. The molecular composition of lignin in spruce decayed by white-rot fungi (Phanerochaete chrysosporium and Trametes versicolor) using pyrolysis-GC - MS and thermochemolysis with tetramethylammonium hydroxide. International Biodeterioration \& Biodegradation 2003;51:67-75.

[24] del Río JC, Lino AG, Colodette JL, Lima CF, Gutiérrez A, Martínez AT, et al. Differences in the chemical structure of the lignins from sugarcane bagasse and straw. Biomass and Bioenergy 2015;81:322-38. doi:10.1016/j.biombioe.2015.07.006.

[25] Greenhalf CE, Nowakowski DJ, Harms AB, Titiloye JO, Bridgwater A V. A comparative study of straw, perennial grasses and hardwoods in terms of fast pyrolysis products. Fuel 2013;108:216-30. doi:10.1016/j.fuel.2013.01.075.

[26] Chen L, Wang X, Yang H, Lu Q, Li D, Yang Q, et al. Study on pyrolysis behaviors of non-woody lignins with TG-FTIR and Py-GC / MS. Journal of Analytical and Applied Pyrolysis 2015;113:499-507. doi:10.1016/j.jaap.2015.03.018.

[27] Liang J, Lin Y, Wu S, Liu C, Lei M, Zeng C. Enhancing the quality of bio-oil and 
selectivity of phenols compounds from pyrolysis of anaerobic digested rice straw. Bioresource Technology 2015;181:220-3. doi:10.1016/j.biortech.2015.01.056.

[28] Zhou S, Grisel S, Herpoël-Gimbert I, Rosso M-N. A PCR-based method to quantify fungal growth during pretreatment of lignocellulosic biomass. Journal of Microbiological Methods 2015;115:67-70. doi:10.1016/j.mimet.2015.05.024.

[29] Rouches E, Zhou S, Steyer JP, Carrere H. White-Rot Fungi pretreatment of lignocellulosic biomass for anaerobic digestion: impact of glucose supplementation. Process Biochemistry 2016;in press.

[30] Zhou S, Raouche S, Grisel S, Navarro D, Sigoillot J, Herpoël-gimbert I. Solid-state fermentation in multi-well plates to assess pretreatment efficiency of rot fungi on lignocellulose biomass. Microbial Biotechnology 2015. doi:10.1111/1751-7915.12307.

[31] Zhou S. Développement de prétraitements fongiques de biomasses lignocellulosiques en fermentation solide afin d ' améliorer leur transformations énergétiques. Université, 2016.

[32] Sluiter A, Hames B, Ruiz R, Scarlata C, Sluiter J, Templeton D, et al. Determination of Structural Carbohydrates and Lignin in Biomass. NREL. 2011.

[33] APHA. Standard methods for examination of water and wastewater. 1998.

[34] Wikstrom C, Rannar S, Johansson E, Sandberg M. Multivariate process and quality monitoring applied to an electrolysis process Part I. Process supervision with multivariate control charts. Chemometrics and Intelligent Laboratory Systems 1998:221-31.

[35] Buurman P, Peterse F, Martin GA. Soil organic matter chemistry in allophanic soils : a pyrolysis-GC / MS study of a Costa Rican Andosol catena. European Journal of Soil Science 2007:1330-47. doi:10.1111/j.1365-2389.2007.00925.x.

[36] Chen GC, Johnson BR. Improved colorimetric determination of cell wall chitin in wood decay fungi. Applied and Environmental Microbiology 1983;46:13-6.

[37] Mohaček-Grošev V, Božac R, Puppels GJ. Vibrational spectroscopic characterization of wild growing mushrooms and toadstools. Spectrochimica Acta - Part A: Molecular and Biomolecular Spectroscopy 2001;57:2815-29. doi:10.1016/S1386-1425(01)005844.

[38] Hadar Y, Cohen-arazi E. Chemical Composition of the Edible Mushroom Pleurotus ostreatus Produced by Fermentation. Applied and Environmental Microbiology 1986;51:1352-4.

[39] Pouwels AD, Tom A, Eijkel GB, Boon JJ. Characterisation of beech wood and its holocellulose and xylan fractions by pyrolysis-gas-chromatography-mass spectrometry. Journal of Analytical and Applied Pyrolysis 1987;11:417-36.

[40] Nowakowski DJ, Jones JM. Uncatalysed and potassium-catalysed pyrolysis of the cellwall constituents of biomass and their model compounds. Journal of Analytical and Applied Pyrolysis 2008;83:12-25. doi:10.1016/j.jaap.2008.05.007.

[41] Chimphango AF a, van Zyl WH, Görgens JF. Isolation, characterization and enzymatic modification of water soluble xylans from Eucalyptus grandis wood and sugarcane bagasse. Journal of Chemical Technology and Biotechnology 2012;87:1419-29. doi:10.1002/jctb.3761.

[42] Ralph J, Hatfield RD. Pyrolysis-GC-MS characterization of forage materials. Journal of Agricultural and Food Chemistry 1991;39:1426-37. doi:10.1021/jf00008a014. 
[43] Chiavari G, Galletti G. Pyrolysis-gas chromatography / mass spectrometry of amino acids. Journal of Analytical and Applied Pyrolysis 1992;24:123-37.

[44] Lechner BE, Papinutti VL. Production of lignocellulosic enzymes during growth and fruiting of the edible fungus Lentinus tigrinus on wheat straw. Process Biochemistry 2006;41:594-8. doi:10.1016/j.procbio.2005.08.004.

[45] Manu-Tawiah W, Martin a M. Chemical composition of Pleurotus ostreatus mycelial biomass. Food Microbiology 1987;4:303-10.

[46] Hadar Y, Kerem Z, Gorodecki B, Ardon O. Utilization of lignocellulosic waste by the edible mushroom, Pleurotus. Biodegradation 1992;3:189-205. doi:10.1007/BF00129083.

[47] Moldoveanu SC. Pyrolysis GC/MS, present and future (recent past and present needs). Journal of Microcolumn Separations 2001;13:102-25. doi:10.1002/mcs.1028.

[48] Lu Y, Wei X-Y, Cao J-P, Li P, Liu F-J, Zhao Y-P, et al. Characterization of a bio-oil from pyrolysis of rice husk by detailed compositional analysis and structural investigation of lignin. Bioresource Technology 2012;116:114-9. doi:10.1016/j.biortech.2012.04.006.

[49] Gutierrez A, Martinez MJ, Almendros G, Gonzalezvila FJ, Martinez a T. HyphalSheath Polysaccharides in Fungal Deterioration. Science of the Total Environment 1995;167:315-28. doi:10.1016/0048-9697(95)04592-O.

[50] Walker GM, White NA. Introduction to fungal physiology. Wiley; 2005.

[51] van der Kaaden a, Boon JJ, Haverkamp J. The Analytical Pyrolysis of Carbohydrates 2. Biomedical Mass Spectrometry, Vol 11, No 9 1984;11:486-93.

[52] Moldoveanu SC. Analytical pyrolysis of natural organic polymers. vol. 20. Elsevier; 1998.

[53] Kalač P. Chemical composition and nutritional value of European species of wild growing mushrooms: A review. Food Chemistry 2009;113:9-16. doi:10.1016/j.foodchem.2008.07.077.

[54] Obatake Y. Changes in low molecular weight carbohydrates composition and chitin throughout the cultivation stages of Pleurotus ostreatus. Mycoscience 1998;39:481-5.

[55] Ross a. B, Anastasakis K, Kubacki M, Jones JM. Investigation of the pyrolysis behaviour of brown algae before and after pre-treatment using Py-GC/MS and TGA. Journal of Analytical and Applied Pyrolysis 2009;85:3-10. doi:10.1016/j.jaap.2008.11.004.

[56] Sun R. Cereal straw as a resource for sustainable biomaterials and biofuels: chemistry, extractives, lignins, hemicelluloses and cellulose. Access Online via Elsevier; 2010.

[57] Reeves JB, Galletti GC. Use of pyrolysis - gas chromatography/mass spectrometry in the study of lignin assays. Journal of Analytical and Applied Pyrolysis 1993;24:24355. doi:10.1016/0165-2370(93)85004-I.

[58] Camarero S, Bocchini P, Galletti GC, Martínez AT. Pyrolysis-gas chromatography/mass spectrometry analysis of phenolic and etherified units in natural and industrial lignins. Rapid Communications in Mass Spectrometry 1999;13:630-6.

[59] Dignac MF, Pechot N, Thevenot M, Lapierre C, Bahri H, Bardoux G, et al. Isolation of soil lignins by combination of ball-milling and cellulolysis: Evaluation of purity and isolation efficiency with pyrolysis/GC/MS. Journal of Analytical and Applied Pyrolysis 
2009;85:426-30. doi:10.1016/j.jaap.2008.10.012.

[60] Terrón MC, Fidalgo ML, Galletti GC, González AE. Pyrolysis-gas chromatography/mass spectrometry of milled wood lignin of two Chilean woods naturally decayed by Ganoderma australe, Phlebia chrysocrea and a brown-rot fungus. Journal of Analytical and Applied Pyrolysis 1995;33:61-75. doi:10.1016/01652370(94)00861-T.

[61] Amen-Chen C, Pakdel H, Roy C. Production of monomeric phenols by thermochemical conversion of biomass: A review. Bioresource Technology 2001;79:277-99. doi:10.1016/S0960-8524(00)00180-2.

[62] Lee J. Biological conversion of lignocellulosic biomass to ethanol. Journal of Biotechnology 1997;56:1-24.

[63] Río JC Del, Rencoret J, Prinsen P, Martinéz ÁT, Ralph J, Gutiérrez A. Structural Characterization of Wheat Straw Lignin as Revealed by Analytical Pyrolysis, 2DNMR, and Reductive Cleavage Methods. J Agric Food Chem 2012:5922-35.

[64] Terrón MC, Fidalgo ML, González AE, Almendros G, Galletti GC. Pyrolysis-gas chromatography / mass spectrometry of wheat straw fractions obtained by alkaline treatments used in pulping processes. Journal of Analytical and Applied Pyrolysis 1993;27:57-71.

[65] Hedges JI, Ertel JR. Characterization of lignin by gas capillary chromatography of cupric oxide oxidation products. Analytical Chemistry 1982;54:174-8.

[66] Lapierre C. Determining Lignin Structure by Chemical Degradations. ' $\square f$ Lignin and Lignans: Advances in Chemistry, Heitner, Cyril Dimmel, Donald R. Schimidt, John a.; 2010, p. 629.

[67] Fidalgo ML, Terron MC, Martinez AT, Gonzalez AE, Gonzalez-Vila FJ, Galletti GC. Comparative study of fractions from alkaline extraction of wheat straw through chemical degradation, analytical pyrolysis, and spectroscopic techniques. Journal of Agricultural and Food Chemistry 1993;41:1621-6. doi:10.1021/jf00034a019.

[68] Tsuge S, Matsubara H. High-resolution pyrolysis-gas chromatography of proteins and related materials. Journal of Analytical and Applied Pyrolysis 1985;8:49-64.

[69] Sun R, Lawther JM, Banks WB. The effect of alkaline nitrobenzene oxidation conditions on the yield and components of phenolic monomers in wheat straw lignin and compared to cupric(II) oxidation. Industrial Crops and Products 1995;4:241-54. doi:10.1016/0926-6690(95)00038-0.

[70] Lapierre C, Monties B, Rolando C. Thioacidolysis of diazomethane-methylated Pine compression wood and Wheat straw in situ lignins 1988;42:409-11.

[71] Nunes CA, Lima CF, Barbosa LCA, Colodette JL, Gouveia AFG, Silvério FO. Determination of Eucalyptus spp lignin S / G ratio : A comparison between methods. Bioresource Technology 2010;101:4056-61. doi:10.1016/j.biortech.2010.01.012.

[72] Lima CF, Barbosa LC a, Marcelo CR, Silvério FO, Colodette JL. Comparison between analytical pyrolysis and nitrobenzene oxidation for determination of syringyl/guaiacyl ratio in Eucalyptus spp. Lignin. BioResources 2008;3:701-12.

[73] Ohra-aho T, Gomes FJB, Colodette JL, Tamminen T. Simultaneous detection of lignin structure , S / G ratio and carbohydrate composition from Eucalyptus hybrids by analytical pyrolysis-GC / MS. 6th International Colloquium on Eucalyptus Pulp, 2013, p. $1-8$. 
[74] Branca C, Giudicianni P, Di Blasi C. GC/MS characterization of liquids generated from low-temperature pyrolysis of wood. Industrial \& Engineering Chemistry Research 2003;42:3190-202. doi:10.1021/ie030066d.

[75] Lv G, Wu S. Analytical pyrolysis studies of corn stalk and its three main components by TG-MS and Py-GC/MS. Journal of Analytical and Applied Pyrolysis 2012;97:11-8. doi:10.1016/j.jaap.2012.04.010.

[76] Mészáros E, Jakab E, Várhegyi G. TG/MS, Py-GC/MS and THM-GC/MS study of the composition and thermal behavior of extractive components of Robinia pseudoacacia. Journal of Analytical and Applied Pyrolysis 2007;79:61-70.

doi:10.1016/j.jaap.2006.12.007.

[77] De la Rosa JM, González-Pérez J a., González-Vázquez R, Knicker H, López-Capel E, Manning D a C, et al. Use of pyrolysis/GC-MS combined with thermal analysis to monitor $\mathrm{C}$ and $\mathrm{N}$ changes in soil organic matter from a Mediterranean fire affected forest. Catena 2008;74:296-303. doi:10.1016/j.catena.2008.03.004.

[78] Abdul Aziz SM, Wahi R, Ngaini Z, Hamdan S. Bio-oils from microwave pyrolysis of agricultural wastes. Fuel Processing Technology 2013;106:744-50. doi:10.1016/j.fuproc.2012.10.011. 


\section{Figure captions}

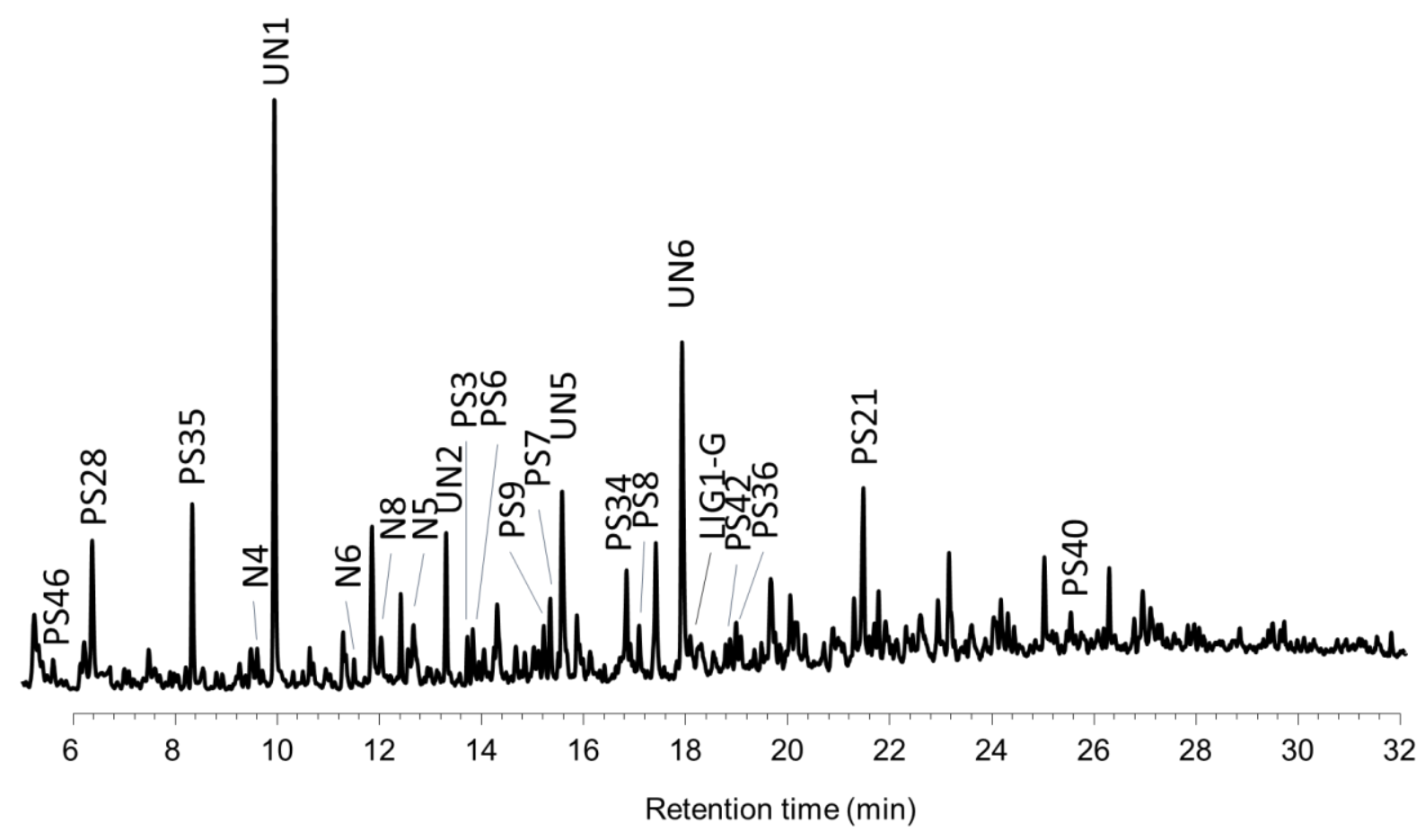

Fig. 1. Pyrogram of mycelium of Polyporus brumalis BRFM 985. Compounds codes are reported in Table 2 except for N5, N6 and N8 that correspond to pyridine, 3-methyl; pyridine, 2-methyl-; 1H-pyrrole, 2-methyl-, respectively. 


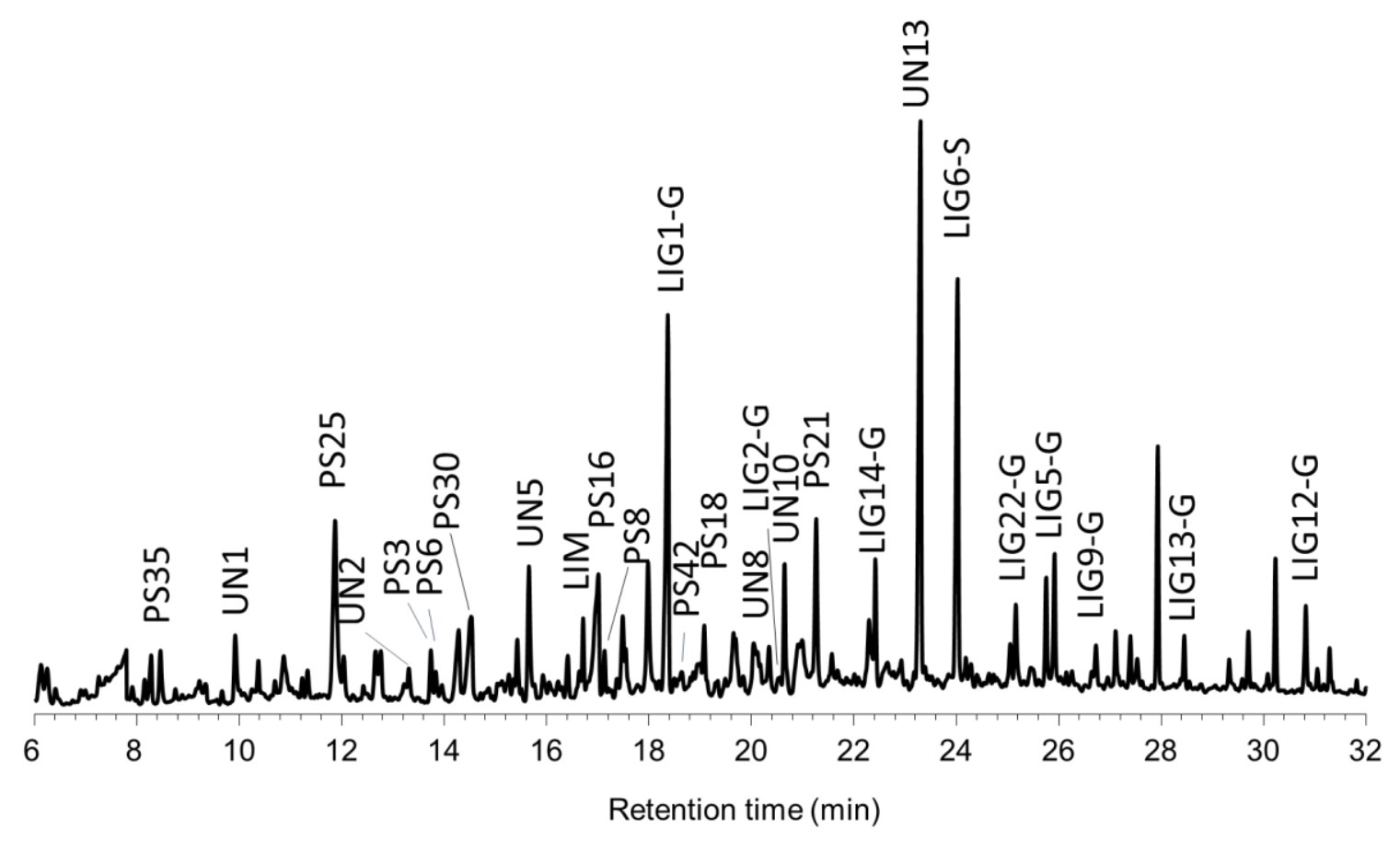

b

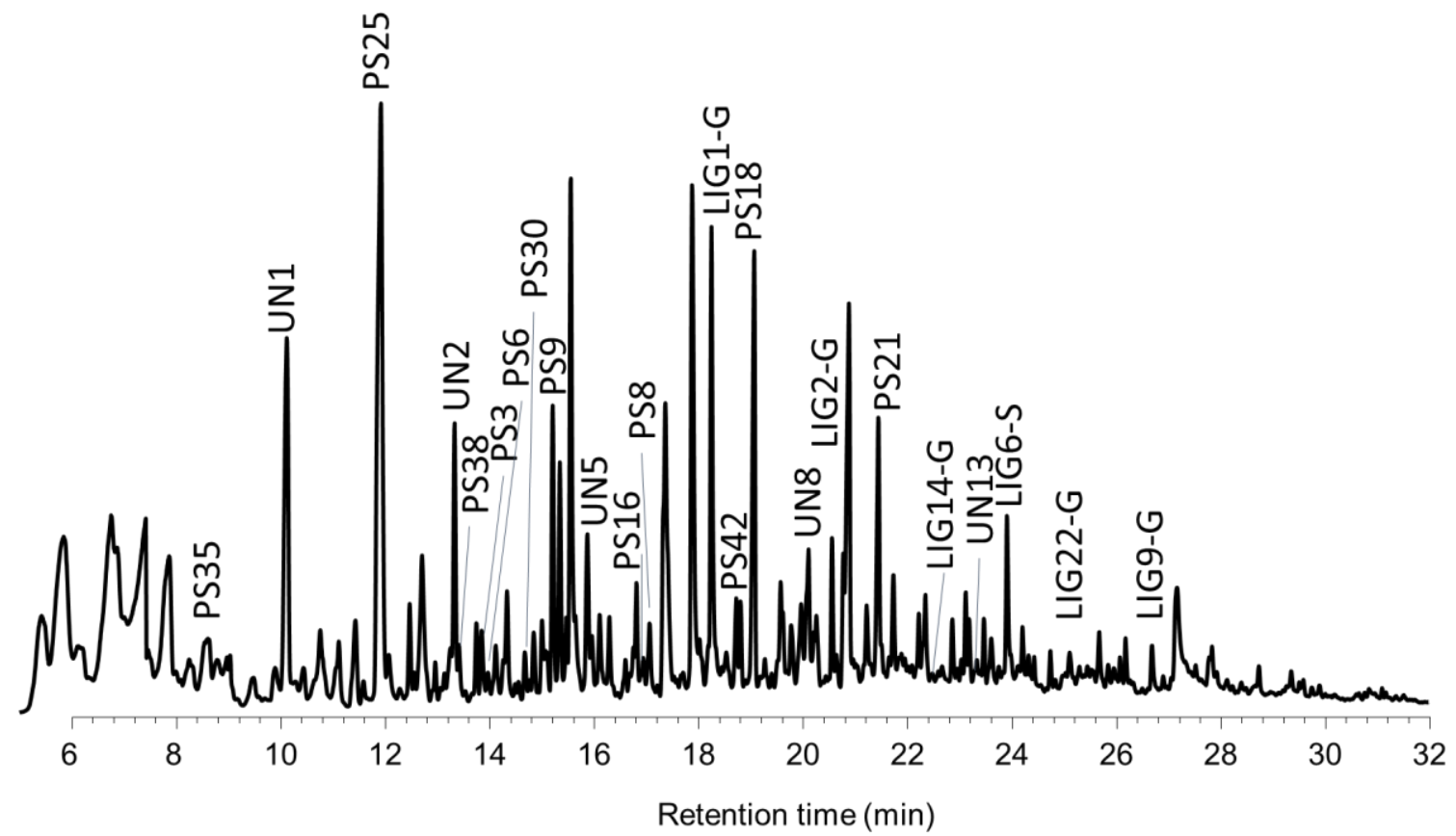

Fig. 2. Pyrogram of (a) untreated wheat straw (UWS) and (b) fungal treated straw with Trametes ljubarskii BRFM 957 strain. Compound codes are reported in Table 2. 
Figure 3

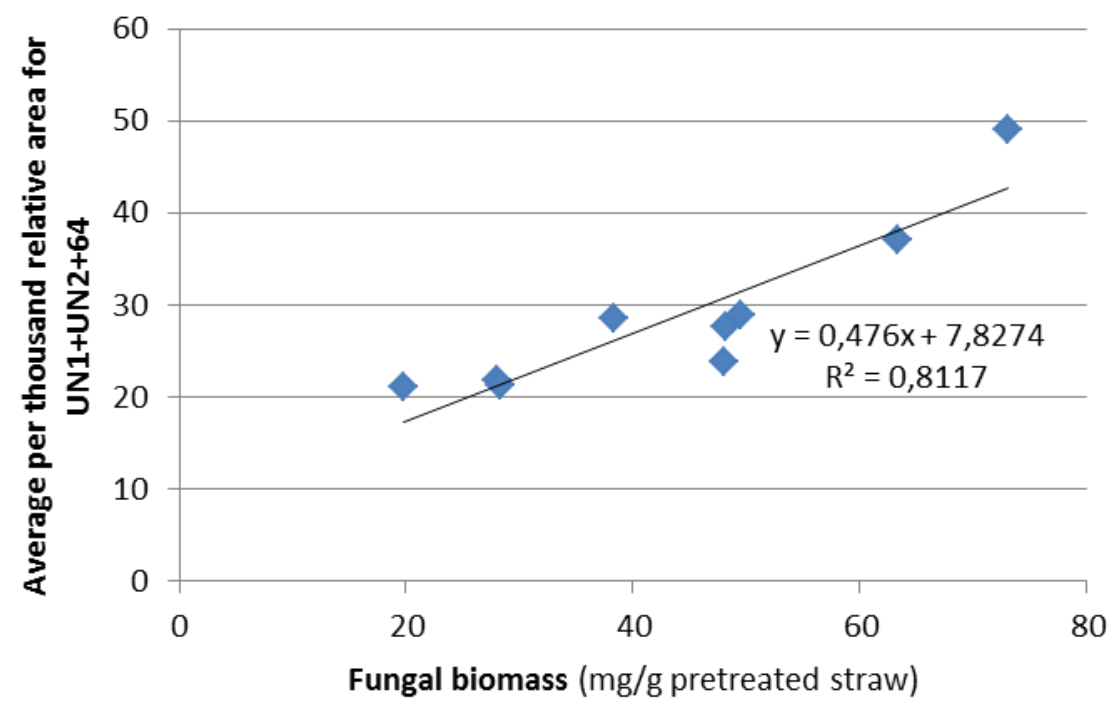

Fig. 3. Fungal biomass amounts estimated with Py-GC-MS and qPCR. Linear correlation between the sum of relative areas of toluene (UN1), styrene (UN2) and ethylbenzene (64) (Py-GC-MS) and fungal biomass (qPCR). This graph is plotted with all samples measured with qPCR: 957, 985, 1048, 1554, 982-2w, 1554-2w, C1, C2 and C9. 


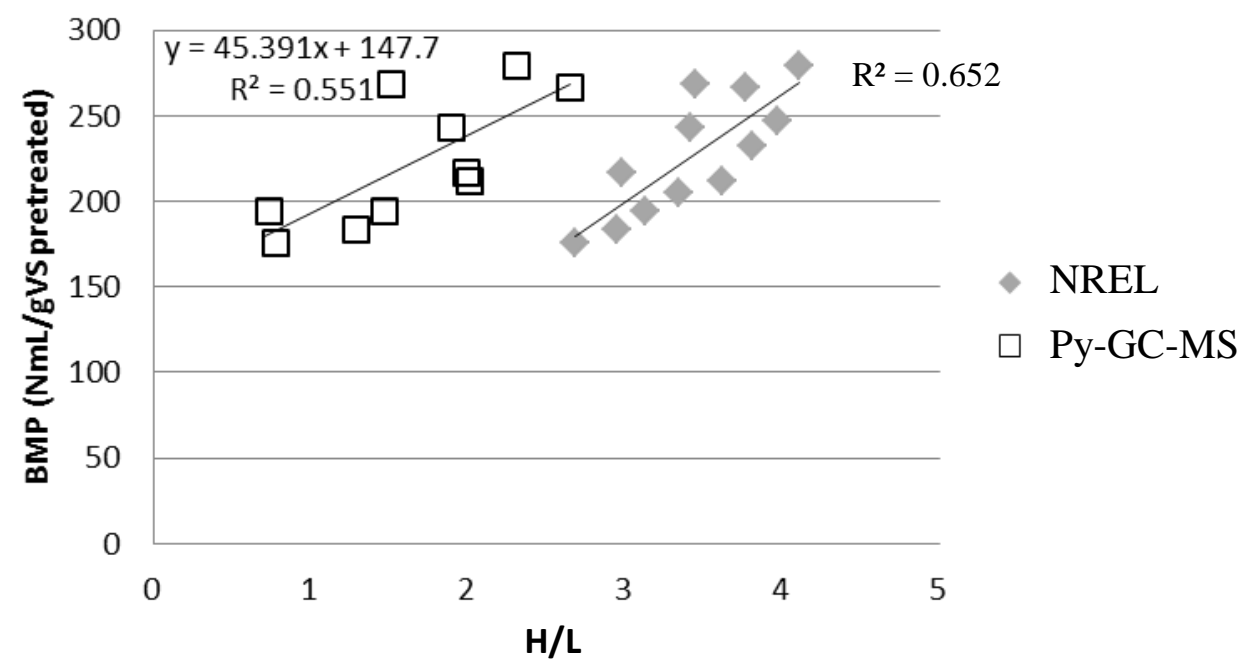

Fig. 4. Correlation between BMP and H/L ratio determined with Py-GC-MS or the NREL method for straw samples. BMP versus H/L-Py is plotted with samples 236, 957, 985, 1296, 1554, C2, C9, C15, C17 and UWS. BMP versus H/L-NREL is plotted with samples 236, 957, 985, 1048, 1296, 1554, C1, C2, C9, C13, C15 and C17. 
Table 1. Strains and pretreatment conditions for straw samples analysed with Py-GC-MS and their BMP. N. A.: Not Available.

\begin{tabular}{|c|c|c|c|c|c|c|}
\hline Samples & Strains & $\begin{array}{c}\text { Metals } \\
\text { addition }\end{array}$ & $\begin{array}{c}\text { Culture } \\
\text { duration } \\
\text { (d) }\end{array}$ & $\begin{array}{c}\text { Temperature } \\
\left({ }^{\circ} \mathrm{C}\right)\end{array}$ & $\begin{array}{l}\text { Initial } \\
\text { WW/TS }\end{array}$ & BMP \\
\hline 1554 & \multirow{2}{*}{ Trametes pavonia } & \multirow{8}{*}{ No } & 21 & \multirow{8}{*}{28} & 4.25 & $212 \pm 2$ \\
\hline $1554-2 w$ & & & 14 & & 4.5 & N.A. \\
\hline 957 & Trametes ljubarskii & & \multirow{5}{*}{21} & & \multirow{5}{*}{4.25} & $266 \pm 23$ \\
\hline 236 & Gloeophyllum trabeum & & & & & $217 \pm 43$ \\
\hline 1296 & Trametes cingulata & & & & & $243 \pm 3$ \\
\hline 1048 & Leiotrametes sp. & & & & & $232 \pm 2$ \\
\hline 985 & \multirow{8}{*}{ Polyporus brumalis } & & & & & $280 \pm 5$ \\
\hline $985-2 w$ & & & 14 & & 4.5 & N.A. \\
\hline C1 & & Yes & 17.5 & 25 & 4.5 & $247 \pm 14$ \\
\hline $\mathrm{C2}$ & & Yes & 12.5 & 25 & 2.1 & $183 \pm 3$ \\
\hline C9 & & Yes & 12.5 & 30 & 3.7 & $268 \pm 16$ \\
\hline C13 & & No & 17.5 & 25 & 4.5 & $205 \pm 17$ \\
\hline C15 & & No & 17.5 & 20 & 2.9 & $176 \pm 12$ \\
\hline C17 & & No & 12.5 & 30 & 3.7 & $194 \pm 13$ \\
\hline
\end{tabular}


Table 2. Product identification from untreated wheat straw (UWS) and fungal pretreated straws with several strains (identified by their BRFM number) and their average relative areas per thousand and sums, ranged by increased retention time (RT) and per compound class (LIG, N, PS, $\mathrm{UN}$ ) as found in literature. In this table, only peak areas equal to zero represent the absence of a compound, empty cells mean a difficulty to identify the compound (co-elution, peak too small or absent). ${ }^{1}$ grey cells show $\mathrm{SD} /$ mean $>50 \% ;{ }^{2}$ grey cells show compounds detected in less than $4 / 9$ samples; SD: Standard-deviation;

\begin{tabular}{|c|c|c|c|c|c|c|c|c|c|c|c|c|c|c|c|c|c|c|}
\hline $\begin{array}{l}\text { RT } \\
(\min )\end{array}$ & Origin & Compound & Code & Ref. & 236 & 957 & 985 & 1048 & 1296 & 1554 & $\begin{array}{l}985- \\
2 w\end{array}$ & $\begin{array}{l}1554- \\
2 w\end{array}$ & UWS & Mean & SD & $\begin{array}{c}\mathrm{SD}^{1} \\
(\% \\
\text { mean })\end{array}$ & Occurr & nce $^{2}$ \\
\hline 18.3 & \multirow{12}{*}{ LIG } & Phenol, 2-methoxy- & LIG1-G & {$[18]$} & 24.6 & 25 & 19 & 20.8 & 11.1 & 21.2 & 51.4 & 40 & 63.5 & 30.7 & 17.2 & 56 & 9 & 19 \\
\hline 20.4 & & $\begin{array}{l}\text { Phenol, 3-methoxy-2- } \\
\text { methyl- }\end{array}$ & $\begin{array}{l}\text { LIG18- } \\
\text { G }\end{array}$ & {$[32]$} & & & & & & & & 7.1 & & 7.1 & & & 1 & 19 \\
\hline 20.6 & & $\begin{array}{l}\text { Phenol, 2-methoxy-4- } \\
\text { methyl- }\end{array}$ & LIG2-G & {$[18]$} & 15.2 & 8.2 & 8.1 & 5.2 & 6 & 12.3 & 14 & 18.4 & 19.3 & 11.9 & 5.3 & 44.4 & 9 & 19 \\
\hline 21.5 & & Phenol, 3-methoxy- & $\begin{array}{l}\text { LIG17- } \\
\text { G }\end{array}$ & & & & & & & & & 2.2 & & 2.2 & & & 1 & 19 \\
\hline 22.4 & & $\begin{array}{l}\text { Phenol, 4-ethyl-2- } \\
\text { methoxy- }\end{array}$ & $\begin{array}{l}\text { LIG14- } \\
\text { G }\end{array}$ & {$[32]$} & & 11 & 9.3 & 7.5 & 11.1 & & 12.5 & & 18.8 & 11.6 & 3.9 & 33.5 & 6 & 19 \\
\hline 24 & & $\begin{array}{l}\text { Phenol, 2,6- } \\
\text { dimethoxy- }\end{array}$ & LIG6-S & {$[18]$} & 21.6 & 14 & 17 & 12.3 & 13.6 & 23.5 & 49.4 & 42 & 60.1 & 28.1 & 17.8 & 63.3 & 9 & 19 \\
\hline 24.3 & & $\begin{array}{l}\text { Phenol, 3,4- } \\
\text { dimethoxy- }\end{array}$ & $\begin{array}{l}\text { LIG16- } \\
\text { S }\end{array}$ & {$[32]$} & & & & & & & & 7 & & 7 & & & 1 & 19 \\
\hline 24.7 & & $\begin{array}{l}\text { Phenol, 2-methoxy-3- } \\
\text { methyl- }\end{array}$ & $\begin{array}{l}\text { LIG19- } \\
\text { G }\end{array}$ & & 3.5 & & & & & & & & & 3.5 & & & 1 & 19 \\
\hline 25 & & Eugenol & LIG4-G & [18] & & & & & & & 3.6 & 5.6 & 9.3 & 6.2 & 2.9 & 46.8 & 3 & 19 \\
\hline 25.1 & & Vanillin & $\begin{array}{l}\text { LIG22- } \\
\text { G }\end{array}$ & [32] & 11.1 & 4.7 & 7.8 & 8.7 & 8.9 & 7.6 & 8.7 & 8.9 & 9.1 & 7.9 & 2.5 & 31.5 & 9 & 19 \\
\hline 26 & & $\begin{array}{l}\text { Phenol, 2-methoxy-4- } \\
\text { (1-propenyl)- }\end{array}$ & LIG5-G & \multirow[b]{2}{*}[18]{} & 9 & & 4.6 & & 5 & & 12.6 & 12.4 & 16.8 & 10.1 & 4.8 & 47.3 & 6 & 19 \\
\hline 26.7 & & $\begin{array}{l}\text { Ethanone, 1-(4- } \\
\text { hydroxy-3- } \\
\text { methoxyphenyl)- }\end{array}$ & LIG9-G & & 5.4 & 5.4 & & 4.2 & 6.6 & & 8.4 & & & 6 & 1.6 & 26.1 & 5 & 19 \\
\hline
\end{tabular}




\begin{tabular}{|c|c|c|c|c|c|c|c|c|c|c|c|c|c|c|c|c|c|c|}
\hline 28.4 & & $\begin{array}{l}\text { Phenol, 2,6- } \\
\text { dimethoxy-4-(2- } \\
\text { propenyl)- }\end{array}$ & $\begin{array}{l}\text { LIG13- } \\
\mathrm{S}\end{array}$ & & 4.6 & & 2.6 & 6.1 & 5.7 & 16.6 & 7.5 & 10.1 & 12.9 & 8.3 & 4.7 & 56.2 & 8 & 19 \\
\hline 29.7 & & $\begin{array}{l}\text { Benzaldehyde, 4- } \\
\text { hydroxy-3,5- } \\
\text { dimethoxy- }\end{array}$ & $\begin{array}{l}\text { LIG26- } \\
\mathrm{S}\end{array}$ & {$[15]$} & 2.3 & 2.5 & 1.1 & 2.9 & 4 & 2 & & & & 2.1 & 0.7 & 35.9 & 4 & 19 \\
\hline 30.8 & & $\begin{array}{l}\text { Ethanone, 1-(4- } \\
\text { hydroxy-3,5- } \\
\text { dimethoxyphenyl)- }\end{array}$ & $\begin{array}{l}\text { LIG12- } \\
\mathrm{S}\end{array}$ & {$[18]$} & 4.7 & & 4.5 & 3.6 & 6.9 & 4.7 & 7.7 & 4.9 & 7.8 & 5.6 & 1.6 & 28.5 & 8 & 19 \\
\hline 16.7 & & Limonene & LIM & \multirow{2}{*}[18]{} & & & 1.3 & 2.6 & 2.5 & & 6.1 & 6.3 & 8.4 & 4.5 & 2.8 & 61 & 6 & 19 \\
\hline 10.2 & $\mathbf{N}$ & Pyridine & N4 & & & & & & & & & 4.1 & & 4.1 & & & 1 & 19 \\
\hline 6 & \multirow{13}{*}{ PS } & 1,3-cyclopentadiene & PS46 & [39] & 1.7 & 15 & 9 & 5 & 11.8 & 1.8 & 3.7 & 0 & 0 & 5.3 & 5.4 & 101.3 & 9 & 19 \\
\hline 6.2 & & Furan, 2-methyl- & PS28 & {$[15]$} & 6.6 & & & 5.2 & 5 & 23.9 & 9.3 & 19.4 & 9.1 & 11.2 & 7.4 & 66.2 & 7 & /9 \\
\hline 8.5 & & Furan, 2,5-dimethyl- & PS35 & {$[35]$} & 3.1 & 8.8 & 4.2 & 3.3 & 5.7 & 6.4 & 3 & 1.8 & 5.7 & 4.7 & 2.2 & 46.5 & 9 & 19 \\
\hline 11.4 & & 3-furaldehyde & PS37 & [39] & & 5.4 & 4.3 & & 6 & & & & & 5.2 & 0.9 & 16.7 & 3 & 19 \\
\hline 12 & & Furfural & PS25 & {$[40]$} & 138 & 42 & & 61.2 & 46.8 & 130 & 33.1 & 26.3 & 37.3 & 64.3 & 44.3 & 68.9 & 8 & 19 \\
\hline 12.3 & & 2-furanmethanol & PS12 & [18] & & & 1.9 & & & & & & & 1.9 & & & 1 & 19 \\
\hline 13.4 & & $\begin{array}{l}\text { 2-cyclopentene-1,4- } \\
\text { dione }\end{array}$ & PS38 & {$[15]$} & 0 & 5.5 & 1 & 4.2 & 2.6 & & 2.1 & & 5.2 & 2.9 & 2.1 & 71.5 & 7 & $/ 9$ \\
\hline 13.8 & & $\begin{array}{l}\text { 2-cyclopenten-1-one, } \\
\text { 2-methyl- }\end{array}$ & PS3 & {$[18]$} & 1.7 & 3.8 & 3.9 & 4.5 & 3.7 & 2.3 & 6.8 & 6.3 & 7.2 & 4.5 & 2 & 43.8 & 9 & 19 \\
\hline 13.9 & & $\begin{array}{l}\text { Ethanone, 1-(2- } \\
\text { furanyl)- }\end{array}$ & PS6 & & 2.5 & 3.4 & 3.3 & 3.5 & 3.3 & 2.6 & 5.3 & 5.2 & 4.9 & 3.8 & 1.1 & 28.8 & 9 & $/ 9$ \\
\hline 14.1 & & $2(5 \mathrm{H})$-furanone & PS29 & [75] & & & 7.4 & 12.6 & & & 15.5 & & & 11.8 & 4.1 & 34.8 & 3 & 19 \\
\hline 14.6 & & 1,2-cyclopentanedione & PS30 & {$[76]$} & 0 & 11 & 23 & 26.5 & 12 & & 24.8 & 20.3 & 25.3 & 17.8 & 9.3 & 52.5 & 8 & 19 \\
\hline 15.2 & & $\begin{array}{l}\text { 2- } \\
\text { furancarboxaldehyde, } \\
\text { 5-methyl- }\end{array}$ & PS9 & {$[18]$} & 8.6 & 9.7 & 8.2 & 8.6 & 7.4 & 16.9 & 6.5 & 5.3 & 6.8 & 8.7 & 3.3 & 38.6 & 9 & 19 \\
\hline 15.5 & & $\begin{array}{l}\text { 2-cyclopenten-1-one, } \\
\text { 3-methyl- }\end{array}$ & PS7 & & 3.8 & & 6.1 & 10.3 & & 3.6 & 9 & 9.3 & 9.1 & 7.3 & 2.8 & 37.8 & 7 & 19 \\
\hline
\end{tabular}




\begin{tabular}{|c|c|c|c|c|c|c|c|c|c|c|c|c|c|c|c|c|c|c|}
\hline 16.9 & & $\begin{array}{l}1,2- \\
\text { cyclopentanedione, } 3- \\
\text { methyl- }\end{array}$ & PS16 & & 9.2 & 8.3 & 13 & 11.6 & 9.1 & & 28.7 & 20.5 & 32.5 & 16.6 & 9.5 & 57.3 & 8 & 19 \\
\hline 17 & & $\begin{array}{l}\text { 2-cyclopenten-1-one, } \\
\text { 2,3-dimethyl- }\end{array}$ & PS8 & & & 6.2 & 3.9 & 4 & 4 & & 8 & 6.9 & 6.8 & 5.7 & 1.7 & 29.7 & 7 & 19 \\
\hline 17.1 & & $\begin{array}{l}\text { 2-cyclopenten-1-one, } \\
\text { 2-hydroxy-3-methyl- }\end{array}$ & PS34 & {$[40]$} & & & & & & 6.2 & & & & 6.2 & & & 1 & 19 \\
\hline 18.8 & & Benzofuran, 2-methyl- & PS42 & {$[77]$} & 3.6 & 7.1 & 6.3 & & 6.1 & 11.2 & & 4.5 & & 6.5 & 2.6 & 41 & 6 & 19 \\
\hline 19 & & $\begin{array}{l}\text { 2-Cyclopenten-1-one, } \\
\text { 3-ethyl-2-hydroxy- }\end{array}$ & PS31 & {$[40]$} & & & & & & & & & 9.2 & 9.2 & & & 1 & 19 \\
\hline 19 & & $\begin{array}{l}1,3- \\
\text { Cyclopentanedione, } \\
\text { 2,2-dimethyl- }\end{array}$ & PS33 & & & & & & & & 10.5 & & & 10.5 & & & 1 & 19 \\
\hline 19 & & Maltol & PS36 & {$[39]$} & & & 6.4 & & & & & & & 6.4 & & & 1 & 19 \\
\hline 19.1 & & Levoglucosenone & PS18 & {$[18]$} & 0 & 8.4 & 5.3 & 15 & 13.5 & & 5.8 & PS31 & 3.5 & 7.4 & 5.4 & 72.9 & 8 & 19 \\
\hline 21.5 & & $\begin{array}{l}\text { 1,4:3,6-dianhydro- } \alpha \text { - } \\
\text { D-glucopyranose }\end{array}$ & PS21 & [15] & 16.8 & 15 & 13 & 14 & 5.9 & & 9.2 & 6 & 12.3 & 11.5 & 4 & 34.9 & 8 & 19 \\
\hline 21.7 & & $\begin{array}{l}\text { 2- } \\
\text { furancarboxaldehyde, } \\
\text { 5-(hydroxymethyl)- }\end{array}$ & PS26 & & & & 6.7 & 8.6 & 8.7 & & & & & 8 & 1.1 & 13.9 & 3 & 19 \\
\hline 21.7 & & Anhydro-D-mannosan & PS43' & {$[40]$} & & 8.3 & & & & & & & & 8.3 & & & 1 & 19 \\
\hline 23 & & $\begin{array}{l}\text { 5-acetoxymethyl-2- } \\
\text { furaldehyde }\end{array}$ & PS45 & [78] & & 2.1 & & & & & & & & 2.1 & & & 1 & 19 \\
\hline 25.4 & & $\begin{array}{l}\text { 2-methyl-5- } \\
\text { hydroxybenzofuran }\end{array}$ & PS40 & {$[15]$} & & & & & 5.8 & 3.1 & & & & 4.4 & 1.9 & 43.9 & 2 & 19 \\
\hline 27.5 & & $\begin{array}{l}\text { 1,6-anhydro- } \beta \text {-D- } \\
\text { glucopyranose } \\
\text { (levoglucosan) }\end{array}$ & PS24 & {$[18]$} & & 8.2 & & 47.1 & & & & & & 27.6 & 27.5 & 99.6 & 2 & 19 \\
\hline 10 & \multirow{3}{*}{$\mathbf{U N}$} & Toluene & UN1 & [26] & 5.6 & 29 & 16 & 11.9 & 20.4 & 12.2 & 12.5 & 10.8 & 12.2 & 14.5 & 6.7 & 46.2 & 9 & 19 \\
\hline 13.3 & & Styrene & UN2 & & & 18 & 11 & & 9.6 & 7.7 & & & 5.8 & 10.3 & 4.5 & 44.2 & 5 & 19 \\
\hline 15.7 & & Phenol & UN5 & & 13.2 & 24 & 18 & 14.2 & 18 & 22.1 & 28.8 & 26.6 & 25.9 & 21.1 & 5.6 & 26.6 & 9 & 19 \\
\hline
\end{tabular}




\begin{tabular}{|c|c|c|c|c|c|c|c|c|c|c|c|c|c|c|c|c|c|}
\hline 17.5 & Phenol, 4-methyl- & UN6 & & & & 24 & 16.8 & 19.3 & 30.5 & & 28.7 & & 23.8 & 5.9 & 24.7 & 5 & 19 \\
\hline 17.9 & Phenol, 3-methyl- & UN7 & & 14.8 & 33 & & & & & 34.1 & & 34 & 28.9 & 9.4 & 32.5 & 4 & 19 \\
\hline 20 & Phenol, 4-ethyl- & UN8 & & 5.3 & 7.5 & 7.9 & 5.4 & 4.7 & & & 9.6 & 11.1 & 7.4 & 2.4 & 32.9 & 7 & 19 \\
\hline 20.7 & 1,2-benzenediol & UN10 & & 48.6 & & 36 & & & & 31.3 & 32.5 & 16.9 & 33.1 & 11.3 & 34.3 & 5 & 19 \\
\hline 22.2 & $\begin{array}{l}\text { 1,2-benzenediol, 3- } \\
\text { methoxy- }\end{array}$ & UN14 & {$[15]$} & & & & & & 23.8 & 37 & 29 & 18.6 & 27.1 & 7.8 & 28.9 & 4 & 19 \\
\hline 23.4 & $\begin{array}{l}\text { 2-methoxy-4- } \\
\text { vinylphenol }\end{array}$ & UN13 & {$[40]$} & 19.1 & 5.6 & 8.7 & 10.9 & 11.3 & & 31 & 21 & 61.8 & 21.2 & 18.3 & 86.6 & 8 & 19 \\
\hline 23.4 & $\begin{array}{l}\text { 3-methoxy-5- } \\
\text { methylphenol }\end{array}$ & UN15 & {$[15]$} & & 4.3 & & & & & & & & 4.3 & & & 1 & 19 \\
\hline 7.6 & Benzene & 61 & & & & 8.4 & & 24.5 & & & 4.7 & & 12.5 & 10.5 & 84.2 & 3 & 19 \\
\hline 8 & 1-heptene & 62 & & & & 2.4 & & & & & & & 2.4 & & & 1 & 19 \\
\hline 9.4 & $\begin{array}{l}\text { 1,3,5-hexatriene, } 2- \\
\text { methyl- }\end{array}$ & 63 & & & & 1.4 & & & & & & & 1.4 & & & 1 & 19 \\
\hline 12.5 & Ethylbenzene & 64 & & 1.1 & 5.4 & 4.2 & 4 & 4.6 & 2 & & & & 3.6 & 1.6 & 46.1 & 6 & 19 \\
\hline 12.5 & $\begin{array}{l}\text { 5,9-dodecadien-2-one, } \\
\text { 6,10-dimethyl-, } \\
(\mathrm{E}, \mathrm{E}) \text { )- }\end{array}$ & 65 & & & & 2.1 & & & & & & & 2.1 & & & 1 & 19 \\
\hline 12.7 & Xylene (o or p) & 66 & & 3.8 & 12 & 13 & 13.8 & 11.2 & & 10 & 10.7 & 8.4 & 10.3 & 3.2 & 30.5 & 8 & 19 \\
\hline 12.9 & 1-nonene & 67 & & & 2 & 2.4 & & & & & & & 2.2 & 0.2 & 11.2 & 2 & 19 \\
\hline 13.3 & $\begin{array}{l}1,3,5,7- \\
\text { cyclooctatetraene }\end{array}$ & 68 & & & & & & & & 6.4 & 4.6 & & 5.5 & 1.3 & 22.9 & 2 & 19 \\
\hline 14.7 & Benzene, 2-propenyl- & 69 & & & 2.2 & & & & & & & & 2.2 & & & 1 & 19 \\
\hline 15 & $\begin{array}{l}\text { Benzene, 1-ethyl-3- } \\
\text { methyl- }\end{array}$ & 70 & & & & 4 & & 2.1 & & & & & 3 & 1.3 & 43.9 & 2 & 19 \\
\hline 15 & $\begin{array}{l}\text { Benzene, 1-ethyl-2- } \\
\text { methyl- }\end{array}$ & 71 & & & & 2.8 & & & & & & & 2.8 & & & 1 & 19 \\
\hline 15.4 & Benzaldehyde & 72 & & & 11 & & & 3.9 & & & & & 7.5 & 5 & 67.1 & 2 & 19 \\
\hline 15.5 & 1-decene & 73 & & & 4 & 9.8 & & 2.7 & & & & & 5.5 & 3.8 & 68.9 & 3 & 19 \\
\hline 15.9 & $\begin{array}{l}\text { Benzene, 1-methoxy- } \\
\text { 4-methyl- }\end{array}$ & 74 & & & & & & & & & 3.1 & & 3.1 & & & 1 & 19 \\
\hline 15.9 & $\begin{array}{l}\text { Benzene, 1-ethenyl-3- } \\
\text { methyl- }\end{array}$ & 75 & & & 3.9 & 2.6 & & 1.9 & & & & & 2.8 & 1 & 36.6 & 3 & 19 \\
\hline
\end{tabular}




\begin{tabular}{|c|c|c|c|c|c|c|c|c|c|c|c|c|c|c|c|c|}
\hline 15.9 & $\begin{array}{l}\text { Benzene, 1,3,5- } \\
\text { trimethyl- }\end{array}$ & 76 & & & & & 4.6 & & & 4.2 & & 4.4 & 0.3 & 6.7 & 2 & 19 \\
\hline 16.1 & Benzofuran & 77 & & 5 & 2.2 & & 4.5 & & & & & 3.9 & 1.5 & 37.9 & 3 & 19 \\
\hline 17.4 & Indene & 78 & & & 3.1 & 3 & 3.8 & 2.4 & & 4 & & 3.3 & 0.6 & 19.5 & 5 & 19 \\
\hline 17.5 & Phenol, 2-methyl- & 79 & & & 15 & 11.2 & 12.1 & & 18.1 & 15.3 & 17 & 14.8 & 2.7 & 18.2 & 6 & $/ 9$ \\
\hline 19.3 & Phenol, 2-ethyl- & 80 & & 2.6 & 1.5 & & 2.8 & & & & & 2.3 & 0.7 & 31.3 & 3 & 19 \\
\hline 19.6 & Phenol, 2,4-dimethyl- & 81 & & 9.3 & 9 & 5.9 & 8.8 & 2.9 & & 13.1 & & 8.2 & 3.5 & 42.3 & 6 & 19 \\
\hline 19.6 & Phenol, 2,5-dimethyl- & 82 & 7.3 & & & 3.9 & 3.9 & 9.2 & & & & 6.1 & 2.6 & 43.7 & 4 & 19 \\
\hline 19.7 & 1H-indene, 1-methyl- & 83 & & 4.1 & 4.4 & & & & & 3.7 & & 4 & 0.3 & 8.4 & 3 & 19 \\
\hline 20.6 & Phenol, 3,5-dimethyl- & 85 & & & & & & & 9.7 & & 22.6 & 16.2 & 9.1 & 56.5 & 2 & 19 \\
\hline 20.8 & Azulene & 86 & & & & & 3.8 & & & & & 3.8 & & & 1 & 19 \\
\hline 21.2 & $\begin{array}{l}\text { Benzofuran, 2,3- } \\
\text { dihydro- }\end{array}$ & 87 & & & & 11.6 & & 7.9 & 13.3 & 8.6 & 18.2 & 11.9 & 4.1 & 34.7 & 5 & $/ 9$ \\
\hline 22.3 & Hydroquinone & 88 & & & & & & & & 10.3 & & 10.3 & & & 1 & 19 \\
\hline 22.7 & $\begin{array}{l}\text { 4-hydroxy-2,4,5- } \\
\text { trimethyl-2,5- } \\
\text { cyclohexadien-1-one }\end{array}$ & 89 & 7.5 & & & & & & & & & 7.5 & & & 1 & 19 \\
\hline 22.8 & $\begin{array}{l}\text { Bicyclo[4.2.0]octa- } \\
\text { 1,3,5-triene }\end{array}$ & 90 & & & 6 & & & & & & & 6 & & & 1 & 19 \\
\hline 22.9 & $\begin{array}{l}\text { 1,2-benzenediol, 4- } \\
\text { methyl- }\end{array}$ & 91 & 20.9 & & & & & & & 11.9 & 10.9 & 14.6 & 5.5 & 38 & 3 & 19 \\
\hline 23 & $\begin{array}{l}\text { Naphthalene, 1- } \\
\text { methyl- }\end{array}$ & 92 & & 4.3 & & & & & & & & 4.3 & & & 1 & 19 \\
\hline 23.1 & $\begin{array}{l}\text { Naphthalene, 2- } \\
\text { methyl- }\end{array}$ & 93 & & & & & 7.9 & & & 3 & & 5.4 & 3.5 & 64.2 & 2 & 19 \\
\hline 23.1 & Benzocycloheptatriene & 95 & & & 3.3 & & & 1.8 & & & & 2.6 & 1.1 & 41.8 & 2 & 19 \\
\hline 23.6 & Phthalic anhydride & 96 & & & & & 6.7 & & & & & 6.7 & & & 1 & 19 \\
\hline 24.2 & Tetradecane & 97 & & 2.3 & 1.6 & & 5.6 & & & & & 3.2 & 2.1 & 66.7 & 3 & 19 \\
\hline 24.2 & 1-Tetradecene & 98 & & 5.4 & & & & & & & & 5.4 & & & 1 & 19 \\
\hline 24.4 & $\begin{array}{l}\text { N-benzyl-2-[1-(4- } \\
\text { methoxy-phenyl)-1H- } \\
\text { tetrazol-5-ylsulfanyl]- } \\
\text { acetamide }\end{array}$ & 99 & & & & & 3 & & & & & 3 & & & 1 & 19 \\
\hline
\end{tabular}




\begin{tabular}{|c|c|c|c|c|c|c|c|c|c|c|c|c|c|c|}
\hline 24.6 & $\begin{array}{l}\text { 1,3-benzenediol, 4- } \\
\text { ethyl- }\end{array}$ & 100 & & & & & & 8.1 & 11.4 & 9.8 & 2.4 & 24.2 & 2 & 19 \\
\hline 25.7 & $\begin{array}{l}\text { 4-methoxy-2-methyl- } \\
\text { 1-(methylthio)benzene }\end{array}$ & 101 & 6.9 & & & & 14.4 & & & 10.7 & 5.3 & 49.7 & 2 & 19 \\
\hline 25.7 & $\begin{array}{l}\text { 2H-pyran-2-one, 3- } \\
\text { acetyl-4-hydroxy-6- } \\
\text { methyl- }\end{array}$ & 102 & & & & 7.2 & & & 15.5 & 11.3 & 5.9 & 51.7 & 2 & 19 \\
\hline 26 & Pentadecane & 103 & 3 & & & & & & & 3 & & & 1 & 19 \\
\hline 26.1 & 1-pentadecene & 104 & & 3.5 & & & & & & 3.5 & & & 1 & 19 \\
\hline 27.1 & $\begin{array}{l}\text { Benzoic acid, 4- } \\
\text { hydroxy-3-methoxy-, } \\
\text { methyl ester }\end{array}$ & 105 & & & 1.9 & 3.2 & & & & 2.6 & 0.9 & 34.6 & 2 & 19 \\
\hline 27.4 & Homovanillyl alcohol & 106 & & & & & & & 5.7 & 5.7 & & & 1 & 19 \\
\hline 28.6 & Fluorene & 107 & 3.9 & & & & & & & 3.9 & & & 1 & 19 \\
\hline 29.5 & 1-Heptadecene & 108 & & 1.9 & & 2 & & & & 1.9 & 0.1 & 4.9 & 2 & 19 \\
\hline 30 & $\begin{array}{l}\text { Cyclohexane, 2-butyl- } \\
\text { 1,1,3-trimethyl- }\end{array}$ & 109 & & 2 & & & & & & 2 & & & 1 & 19 \\
\hline
\end{tabular}


Table 3. Average relative areas for triplicates ranged per pyrolysis compounds for samples from the optimization step (samples pretreated BRFM 985 strain in various conditions) with and Polyporus brumalis BRFM 985 mycelium pyrolysate.

\begin{tabular}{|c|c|c|c|c|c|}
\hline & C17 & C15 & C9 & $\mathrm{C} 2$ & fungus \\
\hline LIG1-G & 14.02 & 22.94 & 24.61 & 21.98 & 4.92 \\
\hline LIG22-G & 3.18 & 10.82 & 10.38 & 8.28 & \\
\hline LIG2-G & 2.81 & 5.77 & 2.43 & 4.56 & \\
\hline LIM & 1.43 & 3.86 & 2.28 & 3.36 & \\
\hline PS21 & 3.64 & 1.69 & 4.69 & 4.79 & 23.73 \\
\hline PS28 & & & & & 18.81 \\
\hline PS3 & & & & & 3.97 \\
\hline PS30 & 6 & 6.31 & 15.01 & 9.67 & \\
\hline PS35 & 2.03 & 0 & 0 & 1.07 & 16.58 \\
\hline PS42 & & & & & 3.04 \\
\hline PS46 & & & & & 3.03 \\
\hline PS6 & & & & & 5.76 \\
\hline PS7 & & & & & 8.85 \\
\hline PS8 & & & & & 5 \\
\hline PS9 & & & & & 6.1 \\
\hline UN1 & 23.93 & 13.5 & 12.96 & 14.49 & 58.11 \\
\hline UN2 & 17.79 & 8.83 & 10.99 & 9.9 & 13.29 \\
\hline UN5 & & & & & 28.84 \\
\hline UN6 & & & & & 39.68 \\
\hline 64 & 6.06 & 3.05 & 3.62 & 4.18 & \\
\hline 66 & 11.42 & 7.59 & 7.58 & 9.21 & 11.33 \\
\hline
\end{tabular}

